\title{
Picroilmenites in Yakutian kimberlites: variations and genetic models
}

\author{
I. V. Ashchepkov ${ }^{1}$, N. V. Alymova ${ }^{2}$, A. M. Logvinova ${ }^{1}$, N. V. Vladykin ${ }^{2}$, S. S. Kuligin ${ }^{1}$, S. I. Mityukhin ${ }^{3}$, H. Downes ${ }^{4}$, \\ Yu. B. Stegnitsky ${ }^{3}$, S. A. Prokopiev ${ }^{3}$, R. F. Salikhov ${ }^{3}$, V. S. Palessky ${ }^{1}$, and O. S. Khmel'nikova ${ }^{1}$ \\ ${ }^{1}$ Sobolev's Institute of Geology and Mineralogy, SD RAS, Novosibirsk, Russia \\ ${ }^{2}$ Vinogradov's Institute of Geochemistry SD RAS, Irkutsk, Russia \\ ${ }^{3}$ ALROSA Open Joint Stock Company, Mirny, Russia \\ ${ }^{4}$ Department of Earth and Planetary Sciences, Birkbeck College, University of London, London, UK
}

Correspondence to: I. V. Ashchepkov (igor.ashchepkov@igm.nsc.ru)

Received: 8 July 2013 - Published in Solid Earth Discuss.: 20 August 2013

Revised: 15 July 2014 - Accepted: 22 July 2014 - Published: 2 September 2014

\begin{abstract}
Major and trace element variations in picroilmenites from Late Devonian kimberlite pipes in Siberia reveal similarities within the region in general, but show individual features for ilmenites from different fields and pipes. Empirical ilmenite thermobarometry (Ashchepkov et al., 2010), as well as common methods of mantle thermobarometry and trace element geochemical modeling, shows long compositional trends for the ilmenites. These are a result of complex processes of polybaric fractionation of protokimberlite melts, accompanied by the interaction with mantle wall rocks and dissolution of previous wall rock and metasomatic associations. Evolution of the parental magmas for the picroilmenites was determined for the three distinct phases of kimberlite activity from Yubileynaya and nearby Aprelskaya pipes, showing heating and an increase of $\mathrm{Fe} \#(\mathrm{Fe \#}=\mathrm{Fe} /(\mathrm{Fe}+\mathrm{Mg})$ a.u. $)$ of mantle peridotite minerals from stage to stage and splitting of the magmatic system in the final stages.

High-pressure (5.5-7.0 GPa) Cr-bearing Mg-rich ilmenites (group 1) reflect the conditions of high-temperature metasomatic rocks at the base of the mantle lithosphere. Trace element patterns are enriched to $0.1-10 /$ relative to primitive mantle (PM) and have flattened, spoon-like or S- or W-shaped rare earth element (REE) patterns with $\mathrm{Pb}>1$. These result from melting and crystallization in melt-feeding channels in the base of the lithosphere, where high-temperature dunites, harzburgites and pyroxenites were formed.
\end{abstract}

Cr-poor ilmenite megacrysts (group 2) trace the hightemperature path of protokimberlites developed as result of fractional crystallization and wall rock assimilation during the creation of the feeder systems prior to the main kimberlite eruption. Inflections in ilmenite compositional trends probably reflect the mantle layering and pulsing melt intrusion during melt migration within the channels. Group 2 ilmenites have inclined REE enriched patterns (10100)/PM with $\mathrm{La} / \mathrm{Yb}_{n} \sim 10-25$, similar to those derived from kimberlites, with high-field-strength elements (HFSE) peaks (typical megacrysts). A series of similar patterns results from polybaric Assimilation + fractional crystallization (AFC) crystallization of protokimberlite melts which also precipitated sulfides $(\mathrm{Pb}<1)$ and mixed with partial melts from garnet peridotites. Relatively low-Ti ilmenites with high-Cr content (group 3) probably crystallized in the metasomatic front under the rising protokimberlite source and represent the product of crystallization of segregated partial melts from metasomatic rocks. Cr-rich ilmenites are typical of veins and veinlets in peridotites crystallized from highly contaminated magma intruded into wall rocks in different levels within the mantle columns. Ilmenites which have the highest trace element contents (1000/PM) have REE patterns similar to those of perovskites.

Low $\mathrm{Cr}$ contents suggest relatively closed system fractionation which occurred from the base of the lithosphere up to the garnet-spinel transition, according to monomineral thermobarometry for Mir and Dachnaya pipes. Restricted trends were detected for ilmenites from Udachnaya and most 
other pipes from the Daldyn-Alakit fields and other regions (Nakyn, Upper Muna and Prianabarie), where ilmenite trends extend from the base of the lithosphere mainly up to $4.0 \mathrm{GPa}$. Interaction of the megacryst forming melts with the mantle lithosphere caused heating and HFSE metasomatism prior to kimberlite eruption.

\section{Introduction}

Magnesian ilmenites or picroilmenites occur in all kimberlites of group I (Boyd and Nixon, 1973; Sobolev, 1974; Dawson and Smith, 1977; Gurney et al., 1979; Schulze et al., 1995; Griffin et al., 1997; Kostrovitsky et al., 2004; Wyatt et al., 2004; Amshinsky and Pokhilenko, 1983; and references there in) and more rarely in kimberlite II or orangeites (Mitchell, 1977). Ilmenites occur as discrete rounded nodules up to $7-8 \mathrm{~cm}$, forming up to $30-90 \mathrm{wt} \%$ of the heavy mineral fraction in weathered kimberlites. Sometimes they occur in intergrowths with phlogopites, olivines (Ol) (Moore et al., 1992; Robles-Cruz et al., 2009), Cr-poor pyropes (Rodionov et al., 1991; Gurney et al., 1979; Smith et al., 1975; Harte and Gurney, 1975; Schulze et al., 2001) or clino- and orthopyroxenes (Dawson and Reid, 1970; Boyd and Nixon, 1973; Rodionov et al., 1988). Ilmenite megacrysts are sometimes zoned and fibrous (Nikolenko and Afanasiev, 2010; Robles-Cruz et al., 2009) and contain blebs from fluid inclusions which suggest rapid crystallization and dissolution in fluid-rich systems (Kopylova et al., 2009).

Ilmenites in pyroxenite xenoliths (McCallister et al., 1975; Pokhilenko et al., 1999; Kopylova et al., 2009; Aulbach et al., 2007) in mica-amphibole-rutile-ilmeniteclinopyroxenes (MARIDs) (Dawson and Smith, 1977; Wagner et al., 1996; Gregoire et al., 2002) and other metasomatic associations (Haggerty, 1983; Gregoire et al., 2002; Simon et al., 2003), including diamond-bearing varieties (Ponomarenko et al., 1971; Pokhilenko et al., 1976) and rarely in eclogites (Smith and Dawson, 1975; Pyle and Haggerty, 1998), were described. Groundmass ilmenites in kimberlites are lower in $\mathrm{MgO}, \mathrm{NiO}$ and $\mathrm{Cr}_{2} \mathrm{O}_{3}$ (Pasteris, 1980; Mitchell, 1986).

Cr-bearing picroilmenites occur in metasomatic veins in peridotites (Grégoire et al., 2002, 2003; Reimers et al., 1998) and at the contacts of megacrystalline assemblages with deformed peridotites (Moore and Lock, 2001). They also form rims on low-Cr grains in polycrystalline ilmenite nodules (Schulze et al., 1995).

Using available data, we investigate the hypothesis of ilmenite megacryst formation during polybaric fractionation of protokimberlite melts (Ashchepkov et al., 2010, 2012, 2013a) in feeder channels and mantle veins and accompanying metasomatic systems. This model develops earlier ideas about crystallization in large pegmatite-like bodies in the base of the subcratonic lithospheric mantle (SCLM) (Gur- ney et al., 1979; Griffin et al., 1997; Moore and Lock, 2001; Moore and Belousova, 2005).

\section{Analytic methods and data set}

Ilmenite grains from seven kimberlite fields were analyzed in the Institute of Geology and Mineralogy (Novosibirsk) using CamebaxMicro and Jeol Superprobe electron microprobes. All analyses were made in wavelength-dispersive (WDS) mode with accelerating voltage $15 \mathrm{kV}$ and a focused beam current of $20 \mathrm{nA}$. A set of natural reference minerals (natural picroilmenite GF -55) and synthetic glasses for calibration (Lavrentyev et al., 1987) and reduction procedure using "Karat program" (Lavrent'ev and Usova, 1994) was applied to obtain the analyses. The relative standard deviation did not exceed $1.5 \%$; the precision was close to $0.02-0.015 \%$ for minor elements. Xenolith analyses include data for 180 veined peridotite and websterite xenoliths from the Sytykanskaya pipe (Fig. 2).

Analyzed ilmenite associations from Mir, Udachnaya, Sytykanskaya and other Yakutian pipes (Alymova, 2006; Alymova et al., 2008; Reimers, 1994) and additional data from pyroxenites (Kuligin, 1997) and peridotites (Malygina, 2000) from Udachnaya (Malygina, 2000; Logvinova et al., 2005; Pokhilenko, 2006; Solov'eva et al., 1997, 2008) were included in the database containing $\sim 7200$ ilmenites from Yakutian kimberlites $(\sim 40000$ minerals altogether) (Ashchepkov et al. 2013a, 2014).

Trace element analyses for $>90$ ilmenites from Yakutian kimberlite concentrates and xenoliths and $\sim 1200$ for other minerals (garnet (Gar), clinopyroxenes (Cpx), phlogopites, etc.) were obtained in the Analytic Centre of IGM on a Finnigan Element ICPMS with a UV LaserProbe using international reference standards NIST 612-614.

The major and trace element compositions and the program for the calculations of pressure-temperature (PT) conditions are available in Supplement, files 1-3.

\section{Variations of picroilmenite compositions in Yakutian kimberlites}

Different textural types of the ilmenite-bearing rocks reveal distinct variations of ilmenite compositions.

\subsection{Megacrysts and their textural variations}

Discrete ilmenite megacrysts (up to $7-9 \mathrm{~cm}$ ) (Fig. 2b) are mostly monocrystals with constant compositions, rather high $\mathrm{MgO}$ and low content of minor components. Polycrystalline structures in Sytykan, Dalnyaya and other pipes often occur in contact with deformed peridotites (Fig. 2a, h). They may include intergranular rutile, perovskite or apatite, similar to those in the Kelsey Lake pipes (USA) (Schulze et al., 1995; Ashchepkov et al., 2001, 2013c). Ulvospinels 


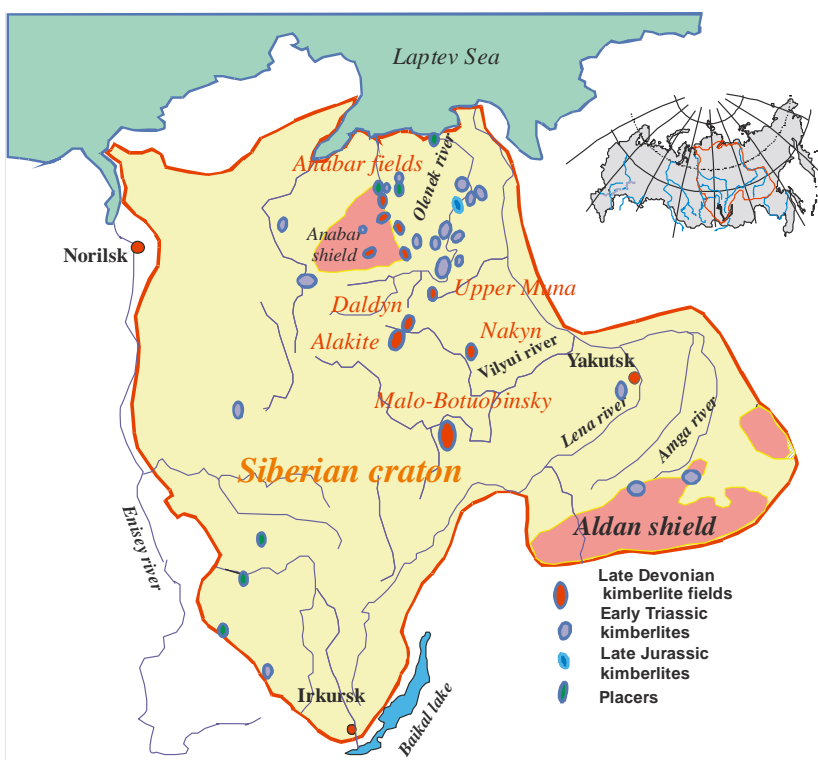

Figure 1. Scheme of the location of kimberlite fields in the Siberian platform.

surround ilmenite grains in Upper Muna pipes (Kostrovitsky and Bruin, 2004).

\subsection{Ilmenites (Ilm) in low-Cr rocks: pyroxenites and intergrowths}

Giant-grained ilmenites intergrowths with olivine, low-Cr clinopyroxenes $\left(<0.4 \mathrm{wt} \% \mathrm{Cr}_{2} \mathrm{O}_{3}\right)$ and garnets are frequent in the Dalnyaya pipe (Fig. 2m, n) (Rodionov et al., 1988) and less common in Udachnaya and in Mir (Alymova et al., 2008; Pokhilenko et al., 1999; Taylor et al., 2003; Roden et al., 2006). Pyropes which are zoned in $\mathrm{CaO}$ (Sobolev et al., 1975) contain picroilmenite inclusions ( $4-5 \mathrm{wt} \% \mathrm{MgO}$, $3.5 \mathrm{wt} \% \mathrm{Cr}_{2} \mathrm{O}_{3}$ ). Ilm-Cpx symplectites occur more rarely in Yakutia compared with South African kimberlites (Dawson and Reid, 1970; Ringwood and Lovering, 1970; Boyd and Nixon, 1973; Gurney et al., 1998).

Giant-grained ilmenite-phlogopite intergrowths and glimmerites, which are common in kimberlites from Anabar and Alakit, contain rutile, apatite and perovskite (Babushkina and Marshintsev, 1997; Ashchepkov et al., 2004).

Group B and C eclogite xenoliths from the Udachnaya and Mir pipes (Beard et al., 1996; Spetsius, 2004; Alymova, 2006) often include ilmenites together with rutile similar to those from the Jericho pipe low-Mg eclogites (Kopylova and Caro, 2004; Heaman et al., 2006) or Mg-rich ilmenites from diamond-bearing eclogites in Koidu kimberlite (Hills and Haggerty, 1989)

\subsection{Ilmenites in peridotite xenoliths}

Rare ilmenite associations with Cr-rich (9$13.5 \mathrm{wt} \% \mathrm{Cr}_{2} \mathrm{O}_{3}$ ), Ti-bearing pyropes (up to $1.5 \mathrm{wt} \%$

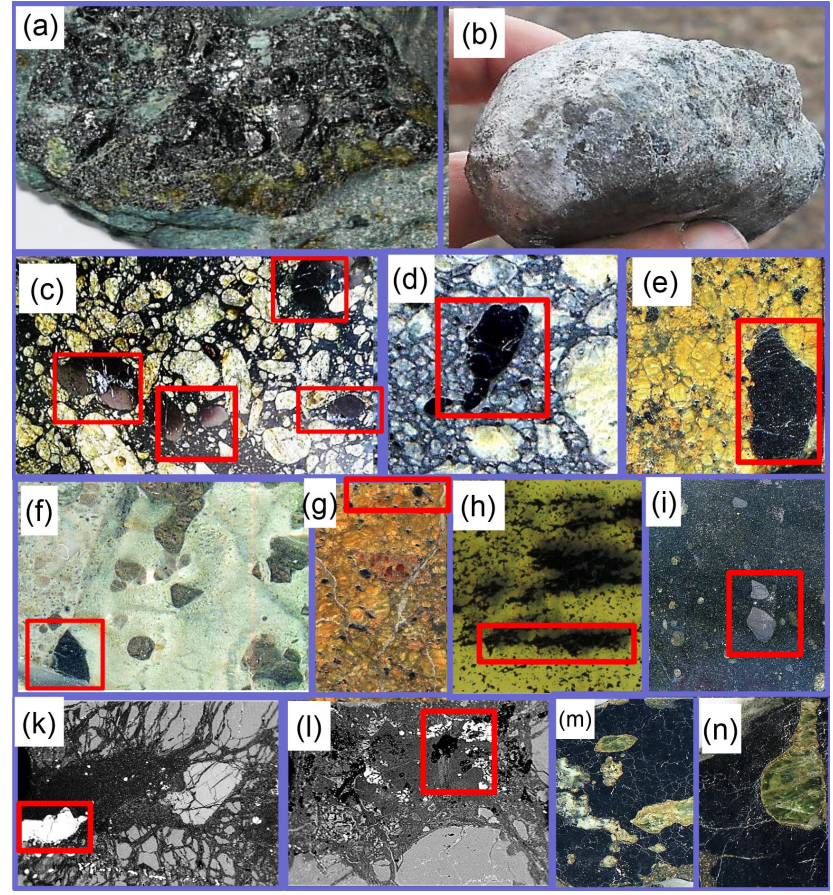

Figure 2. (a) Photograph of ilmenite megacryst in contact with peridotite (Sytykanskaya pipe, sample Stk1); (b) large megacrysts from the Dalnyaya pipe; (c) agglomerate of ilmenite megacrysts and dunite microxenoliths (rarely containing garnets, orthopyroxenes and clinopyroxenes) in kimberlite, Udachnaya pipe; (d) Ilmenite in kimberlite Sytykanskaya pipe; (e) wehrlite with large and small ilmenite grains (Sytykanskaya pipe); (f) image of the thin section of deformed peridotite with ilmenite, mica and clinopyroxenes in intergranular space (Sytykanskaya pipe, sample Stk35); (g) garnet ilmenite-bearing peridotite; (h) deformed peridotite with ilmenite grain (black) (Sytykanskaya pipe); (i) phlogopite breccia with ilmenite xenocrysts, Udachnaya pipe; (k) and (l) ilmenite grains (bright) in thin section of porphyroclastic peridotite (Dalnyay pipe); (m) and (n) clinopyroxene inclusion in ilmenite megacrysts. Separate ilmenite grains are marked by the red squares.

TiO2) in harzburgites from Udachnaya (Fig. 2c) (Alymova, 2008) are similar to those from Kelsey Lake pipes (USA) (Schulze et al., 1995; Ashchepkov et al., 2001; 2013c). Fragments of the contacts of megacrystalline ilmenite with sheared peridotites containing $\mathrm{Cr}$ diopsides similar to those described in South African kimberlites (Moore and Lock, 2001) (Fig. 2a) (9-10 wt \% $\left.\mathrm{MgO} ; 2.5 \mathrm{wt} \% \mathrm{Cr}_{2} \mathrm{O}_{3}\right)$ are found among the xenoliths from the Sytykanskaya pipe and Komsomolskaya pipes (Fig. 2f, h). Porphyroclustic peridotites with ilmenites are common in the Dalnyaya pipe (Fig. 2k, 1). The low-Cr Ilm-Gar wehrlites (Fig. 2e, g) are common in Sytykanskaya and Komsomolskaya pipes; Polycrystalline monomineral ilmenite aggregates sometime intrude peridotites and cut porphyroclasts, suggesting formation from an immiscible oxide liquid (Clarke and Mackay, 1990). 
Zircon-bearing peridotites and Cr-diopside pyroxenites (Dawson et al., 2001) and megacrysts (Spetsius et al., 2002) may also be associated with ilmenites. Highly Cr-rich picroilmenites $\left(2-8 \mathrm{wt} \% \mathrm{Cr}_{2} \mathrm{O}_{3}\right)$ are widespread in metasomatic and veined peridotites (Harte, 1987; Konzett et al., 2000; Dawson et al., 2001; Gregoire et al., 2002) especially in the Alakit region, in Sytykanskaya and Komsomolskaya pipes (Solovieva et al., 1997; Alymova, 2006). Ilmenites are common in high-temperature (HT) dunites and megacrystalline harzburgites (10-12 wt \% $\mathrm{MgO}, 0.8-1.5 \mathrm{wt} \% \mathrm{Cr}_{2} \mathrm{O}_{3}$ ).

Phlogopitic breccias (Fig. 2i) containing microxenolith and olivine xenocrysts are cemented by fine-grained aggregates of phlogopite, diopside, amphibole, Ti chromite and picroilmenite ( $7 \mathrm{wt} \% \mathrm{MgO}$ ); large ilmenites are also found as xenocrysts in breccia (9-10 wt \% MgO) (Ashchepkov et al., 2013b).

\subsection{Ilmenites in diamond-bearing associations in mantle}

Cr-rich ilmenites (7-8 wt $\left.\% \mathrm{Cr}_{2} \mathrm{O}_{3}\right)$ were discovered in rare diamondiferous peridotite xenoliths from Mir (Ponamarenko, 1971) and Udachnaya (Pokhilenko et al., 1976). Diamond inclusions rarely contain Cr-bearing ilmenites $\left(\mathrm{Cr}_{2} \mathrm{O}_{3} 8-12 \mathrm{wt} \%\right)$ as described in the Sputnik pipe (Sobolev et al., 1997) (Fig. 3, shaded area). The highest $\mathrm{Cr}_{2} \mathrm{O}_{3}$ values $(\sim 8 \mathrm{wt} \%)$ are typical of diamond-bearing ilmenite peridotites (Ponomarenko et al., 1971; Pokhilenko et al., 1976), diamond inclusions (Sobolev et al., 1997) and mica glimmerites.

Ilmenites from garnet pyroxenites are lower in $\mathrm{Cr}_{2} \mathrm{O}_{3}$ and higher in $\mathrm{MgO}$ (Fig. 3 shaded area in $\mathrm{TiO}_{2}$ vs. $\mathrm{Al}_{2} \mathrm{O}_{3}$ diagram). $\mathrm{MgO}$-, and $\mathrm{TiO}_{2}$-rich MARIDs all show relatively low $\mathrm{Al}$ and $\mathrm{Cr}$ ilmenites worldwide (Meyer and Svisero, 1975) Commonly, ilmenite diamond inclusions (Taylor and Anand, 2004; Stachel et al., 2004; Sobolev et al., 1997, 2003) are $\mathrm{Cr}$ poor $\left(\mathrm{Cr}_{2} \mathrm{O}_{3}\right.$ wt \% < $\left.0.2 \%\right)$ similar to those from $\mathrm{B}$ and $\mathrm{C}$ type diamond-bearing eclogites (De Stefano et al., 2009). Cr-poor ilmenites (0.04 to $0.23 \mathrm{wt} \% \mathrm{Cr}_{2} \mathrm{O}_{3} ; 9.7$ to $11.3 \mathrm{wt} \% \mathrm{MgO}$ ) occur as intergrowths with type II diamonds (Moore, 2009) in the Mir pipe (Sobolev, 1974) and belong to the megacryst suite. CrMg-poor and Mn-bearing ilmenites occur in diamonds with ultradeep mantle inclusions (Kaminsky et al., 2001; Kaminsky and Belousova, 2009; Wirth et al., 2009). Cloudy diamonds also include nano-crystalline ilmenites together with phlogopites, carbonates and apatites in the dark fluid matter (Logvinova et al., 2008; Sobolev et al., 2009).

\section{Ilmenite compositional trends in Siberian kimberlites}

Variations of ilmenite compositions from xenoliths and concentrates from different kimberlite fields have been studied
(Alymova et al., 2004; Rodionov et al., 1988; Sobolev, 1980; Kostrovitsky et al., 2003) but not systematically.

\subsection{Comparison of trends for xenoliths and concentrates}

Variation diagrams using $\mathrm{TiO}_{2}$ as the pressure-dependent component axis show similarities to plots based on $\mathrm{MgO}$ (Mitchell, 1977; Moore et al., 1992). Regular linear $\mathrm{TiO}_{2-}$ $\mathrm{MgO}$ and $\mathrm{TiO}_{2}-\mathrm{FeO}$ trends (Fig. 3), similar to those for ilmenites from individual pipes (Wyatt et al., 2004), were suggested to be the signs of crystal differentiation of protokimberlite magmas (Griffin et al., 1997) but they refer to different xenolith associations. For example, in the Sytykanskaya pipe where trends for ilmenites from xenoliths and concentrate practically coincide and in Udachnaya, Dalnyaya, and Mir pipes (Supplement 4 Fig. 1 a, b, c) which show overlaps but commonly ilmenites from xenoliths are richer in $\mathrm{Mg}$ and Ti. Ilmenites from low-Cr pyroxenites and xenoliths are rich in $\mathrm{MgO}$ and low in $\mathrm{Ni}$ and $\mathrm{Cr}$.

Various compositional zonations in ilmenite (Schulze et al., 1995; Afanasiev et al., 2008; Robles-Cruz et al., 2009; Reimers et al., 1994) represent contact assemblages, veins, and polymict breccias in Mir, Sytykanskaya, Dalnyaya and other pipes, (Wyatt and Lawless, 1984; Morfi et al., 1999; Zhang et al., 2001; Pokhilenko, 2009; Giuliani et al., 2013). In contrast, large discrete megacryst have rather constant compositions.

\subsection{Comparison of variation trends for different regions}

Short continuous trends ( 55 to $45 \mathrm{wt} \% \mathrm{TiO}_{2}$ ) for ilmenites from the Daldyn pipes (Amshinsky and Pokhilenko, 1983; Rodionov et al., 1988; Pokhilenko et al., 1999; Ashchepkov et al., 2003; Kostrovitsky et al., 2003; Alymova et al., 2004) with negative trends for $\mathrm{FeO}$ and positive for $\mathrm{MgO}$ are determined by crystal chemistry. Plots of $\mathrm{TiO}_{2}$ vs. $\mathrm{Al}_{2} \mathrm{O}_{3}, \mathrm{NiO}$, $\mathrm{Cr}_{2} \mathrm{O}_{3}$ and $\mathrm{V}_{2} \mathrm{O}_{5}$ consist of several separate arrays with varying inclinations (Fig. 5a). Increase in $\mathrm{Fe}$ and incompatible elements accompanies decrease of $\mathrm{MgO}, \mathrm{TiO}_{2}$ and $\mathrm{NiO}$ controlled by olivine fractionation. Decrease of $\mathrm{Al}_{2} \mathrm{O}_{3}$ content probably relates to contamination and precipitation of garnet. The very high $\mathrm{Cr}_{2} \mathrm{O}_{3}$ in the $\mathrm{MgO}-\mathrm{TiO}_{2}$-rich part corresponds to metasomatites from the lithosphere base. Three levels from 0.5 to $2 \mathrm{wt} \% \mathrm{Cr}_{2} \mathrm{O}_{3}$ for ilmenites from the middle part in Zarnitsa (Amshinsky and Pokhilenko, 1983) (Fig. 1a, Supplement 4) and nearby pipes are regulated by different extents of contamination of parental melts. The similarities of the diagram for other pipes in the cluster (Alymova et al., 2004) (Fig. 5a) suggest the same source. Shorter trends were found for ilmenites from the satellite bodies of Zarnitsa pipe. In the heavy mineral concentrate of the micaceous type II kimberlite from the Bukovinskaya pipe (Kostrovitsky and Bruin, 2004), Ti chromites are more common than ilmenites. 


\section{Ilmenites from Kimberlite Xenoliths}
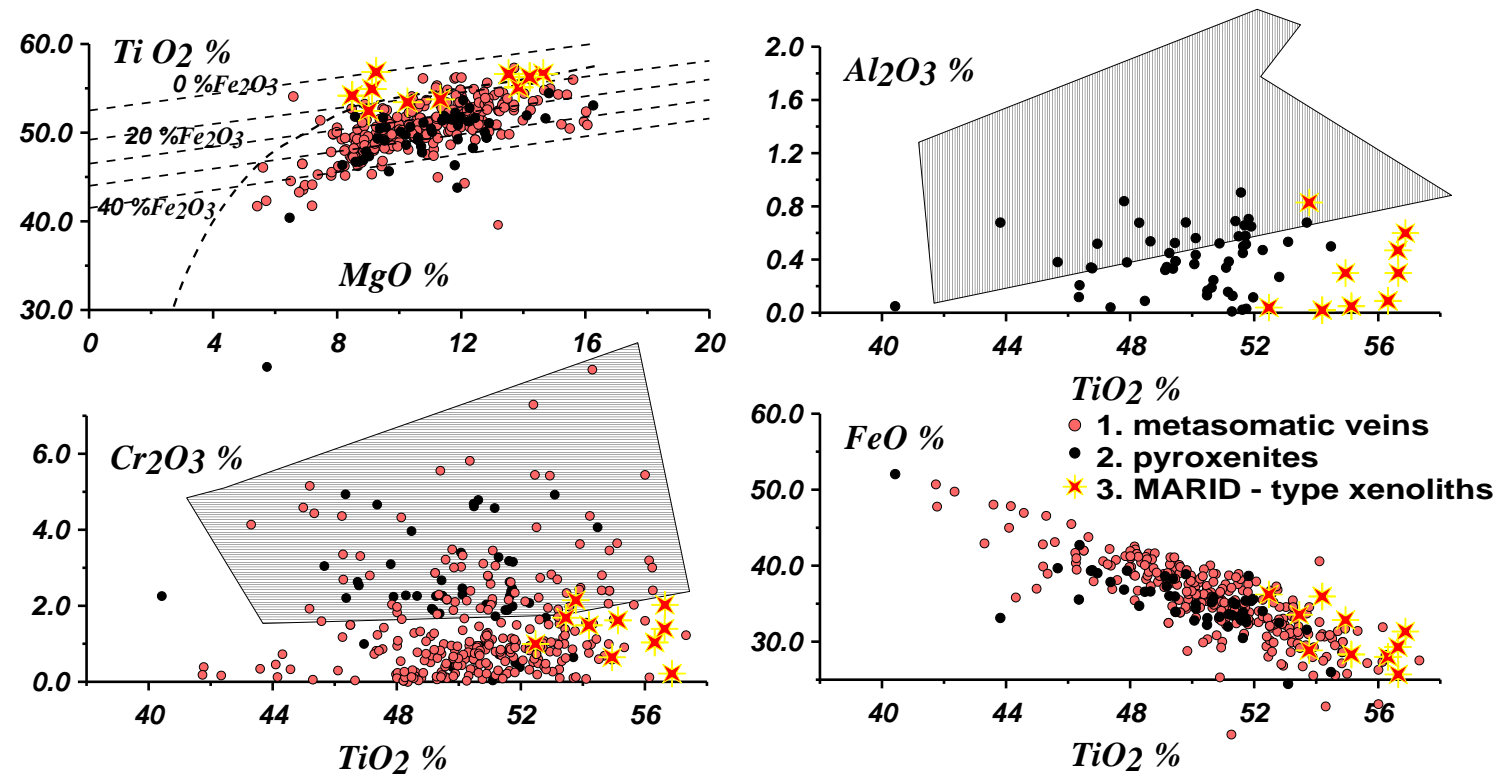

Figure 3. Variation diagram for ilmenite associations in xenoliths using data from literature and new analyses. 1. Ilmenites from metasomatic xenoliths; 2. from pyroxenites; 3 . from MARID-type xenoliths.

Ilmenite trends from kimberlite pipes in the Alakit field show higher $\mathrm{Cr}_{2} \mathrm{O}_{3}$ (Fig. 4, Supplement 4, Fig. 1b). For ilmenites from Sytykanskaya pipe, the $\mathrm{Cr}$ content increases towards the low-Ti part of the diagram is explained by contamination of hydrous parental melts in peridotites accompanied by abundant metasomatism beneath Sytykanskaya and Komsomolskaya pipes (Fig. 4b). The subtrends with 2$6 \mathrm{wt} \% \mathrm{Cr}_{2} \mathrm{O}_{3}$ ranges for Ilm are found within some veined metasomatic $\mathrm{Phl}$ in peridotite xenoliths from Sytykanskaya. For the Aykhal pipe, the restricted $\left(46-53 \mathrm{wt} \% \mathrm{TiO}_{2}\right)$ ilmenite trend may be subdivided into $7-8$ groups. $\mathrm{NiO}$ and $\mathrm{Al}_{2} \mathrm{O}_{3}$ contents decrease rapidly with $\mathrm{TiO}_{2}$.

Ilmenite trends from Malo-Botuobinsky (Mir and Dachnaya) pipes (Ashchepkov et al., 2010, 2013a) (Fig. 4, Supplement 4, Fig. 1c), are long (31-50 wt $\left.\% \mathrm{TiO}_{2}\right)$ and were formed by continuous fractionation, as suggested for South Africa (Moore et al., 1992; Griffin et al., 1997) and Canada (Wyatt et al., 2004). Ti-rich and Cr-poor ilmenites from pyroxenite xenoliths (Alymova, 2006) at the right part of diagram correspond to the SCLM base according to thermobarometry. Low $\mathrm{Ni}$ and $\mathrm{Cr}$ contents are typical. $\mathrm{Cr}$ contents increase at the beginning and end and in the middle part of the crystallization trend. Continuous rise of $\mathrm{Al}_{2} \mathrm{O}_{3}$ suggests lack of garnet among the main precipitating phases. Ilmenites from Amakinskaya and International'naya pipes reveal shorter $\mathrm{TiO}_{2}$ trends divided into four separate intervals.

In the Nakyn field (Lapin et al., 2007) (Fig. 5a), picroilmenites are abundant only in the tuffisitic kimberlites from the Nyurbinskaya pipe showing 55 to $48 \mathrm{wt} \% \mathrm{TiO}_{2}$ interval, while ilmenites found in placer deposits reveal a wider range with a decrease of $\mathrm{NiO}$ and $\mathrm{MgO}$ accompanied by an increase in $\mathrm{FeO}$ and $\mathrm{V}_{2} \mathrm{O}_{5}$ which may be explained by olivine fractionation (Fig. 5a). Metasomatic increase in Cr is accompanied by a decrease in $\mathrm{Al}$.

Picroilmenites from the Deimos pipe in Upper Muna field (Fig. 5b) show 3 levels of $\mathrm{Cr}_{2} \mathrm{O}_{3}$ enrichment which are higher in left part of the trend. Longer and more discrete trends were determined for ilmenites from Zapolyarnaya pipe. Ilmenites from the Poiskovaya pipe are higher in $\mathrm{Al}_{2} \mathrm{O}_{3}$. In the other Upper Muna kimberlite pipes, ilmenites are rare.

In kimberlites from Kuranakh and Ary-Mastakh fields in Prianabarie, ilmenites are more common than chromites. Most ilmenites (42-50 wt \% $\mathrm{TiO}_{2}$ ) show low $\mathrm{Cr}$ content, increasing only for varieties with $>50 \mathrm{wt} \% \mathrm{TiO}_{2}$ (Fig. 5c). Polycrystalline ilmenites from the Nebaibyt pipe have Crrich cores, unlike ilmenites in North American kimberlites (Hunter and Taylor, 1984; Schulze et al., 1995).

\section{Monomineral ilmenite thermobarometry}

The empirical dependence of the geikilite component in ilmenites on pressure was used to indicate the diamond grade of kimberlites (Sobolev, 1977; 1980; Sobolev and Yefimova, 2000). Ilmenite has two types of positions in structure. The distance between $\mathrm{Fe}$ (or $\mathrm{Mg}$ ) and $\mathrm{O}$ is highly dependent from the temperature by 1 order of magnitude more than the distance between Ti and O (Wechsrel et al., 1984).

The $\mathrm{FeTiO}_{3}-\mathrm{MgTiO}_{3}$ internal exchange accounting for the influence of the other components was used for Ol-Ilm 

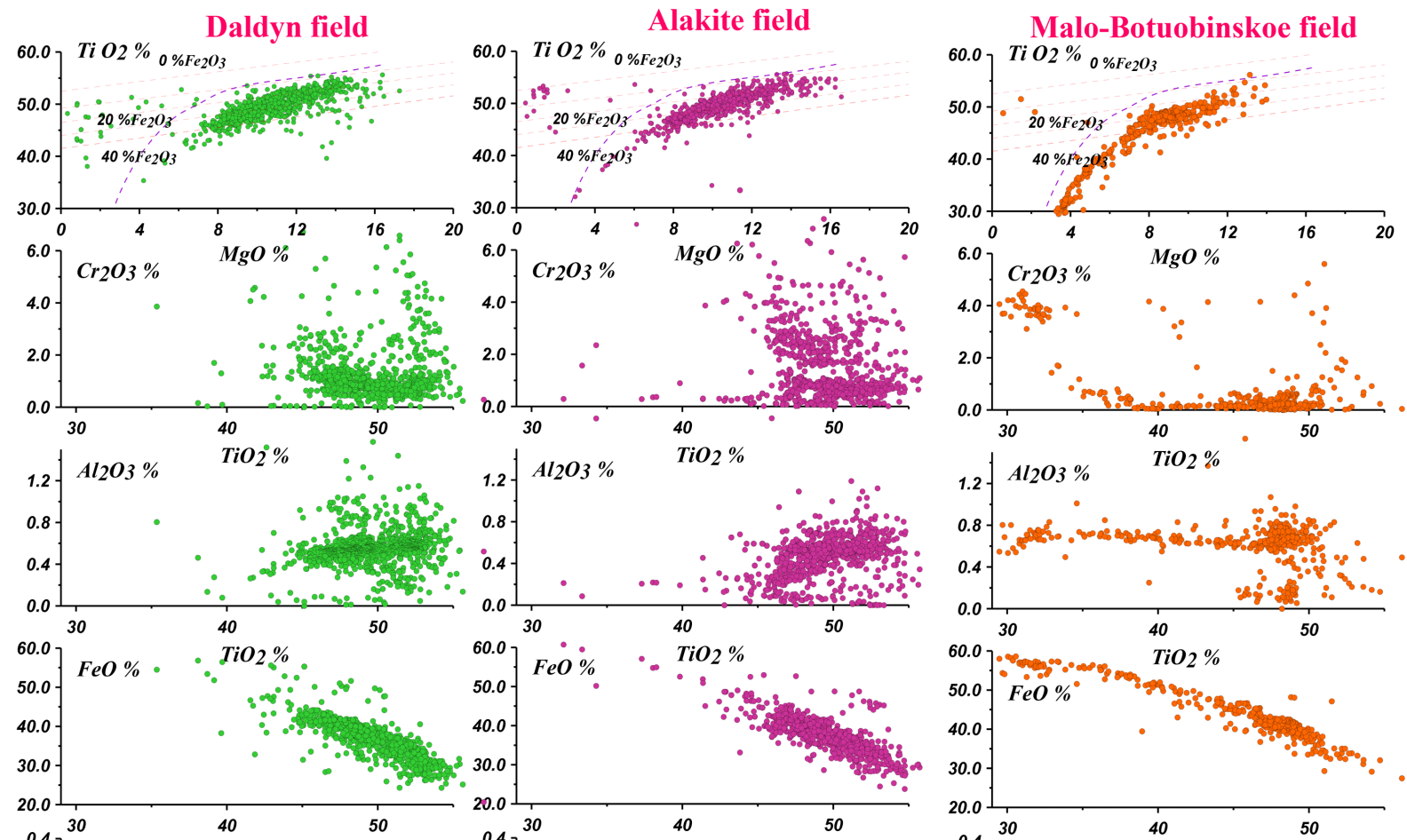

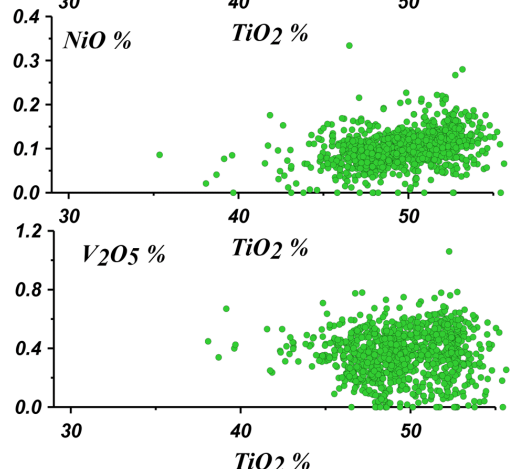

(a)

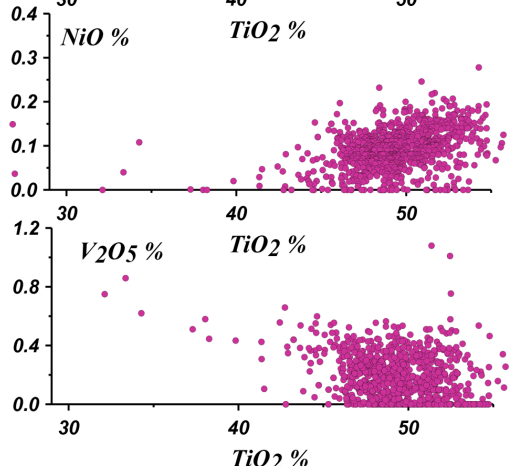

(b)

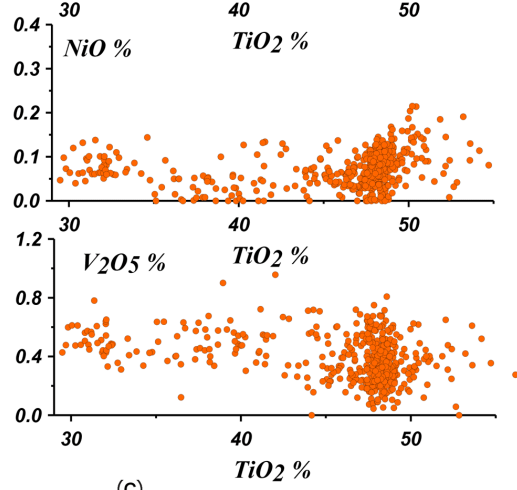

(c)

Figure 4. Variations of ilmenite compositions from different regions Yakutian kimberlite province (Daldyn, Alakit and Malo-Botuobinsky fields).

thermometry (Taylor et al., 1998), which is cited here:

$$
\begin{aligned}
T^{\circ} \mathrm{K} & =(-13715+P \times 1000 \times \mathrm{DVT}+3785 \times(2 \times \mathrm{Fe} \# \mathrm{Ol}-1) \\
& +2830 \times(\mathrm{Gk}-\mathrm{Ilm})-19560 \times \mathrm{Hem}-7840 \times \mathrm{Esk} \\
& +45122 \times \mathrm{Hem} \times \mathrm{Esk}) /(2.231-8.3143 \times \mathrm{Ln}(\mathrm{Kd}))
\end{aligned}
$$

where $\mathrm{Mg} \# \mathrm{Ol}=1-\mathrm{Fe} \# \mathrm{Ol}$;

Esk $=\mathrm{Cr} / 2$ (esklaite);

Hem $=1-$ Esk $-\mathrm{Ti}+\mathrm{Mn}$ (hematite);

all components are given in formula units (f.u.);

$\mathrm{Gk}=\mathrm{Mg}$ (geikilite);

Ilm = $1-$ Esk-Hem-Gk (ilmenite);

$\mathrm{DVT}=0.011(\mathrm{Gk}-\mathrm{Ilm})-0.047+0.015(2 \mathrm{Fe} \# \mathrm{Ol}-1)$

$\mathrm{KD}=(1-\mathrm{Fe} \# \mathrm{Ol}) \mathrm{Ilm} /(\mathrm{Fe} \# \mathrm{Ol} \mathrm{Gk})$.
To obtain agreement with Cpx thermometry (Nimis and Taylor, 1998), the following corrections were introduced

$T^{\circ} \mathrm{K}=\left(T^{\circ} \mathrm{K}-10 \times(25-P)-250+400 \times \mathrm{Hem}\right) \times 0.95$

The monomineralic formulation takes into account the forsterite content

$(\mathrm{Fo}=1-\mathrm{Fe} \# \mathrm{Ol})$

according to

$\mathrm{Fe} \# \mathrm{Ol}(\mathrm{Ilm})=(\mathrm{Fe} \# \mathrm{Ilm}-0.35) / 2.25-0.000035\left(T^{\circ} \mathrm{K}-750\right)($ f.u. $)$,

where Fe\#Ilm $=\mathrm{Fe} /(\mathrm{Fe}+\mathrm{Mg})$.

A further correction:

$\mathrm{Fe} \# \mathrm{Ol}=0.1027 \ln (\mathrm{Fe} \# \mathrm{Ol}(\mathrm{Ilm}))+0.365($ see Fig. 8c $)$ 

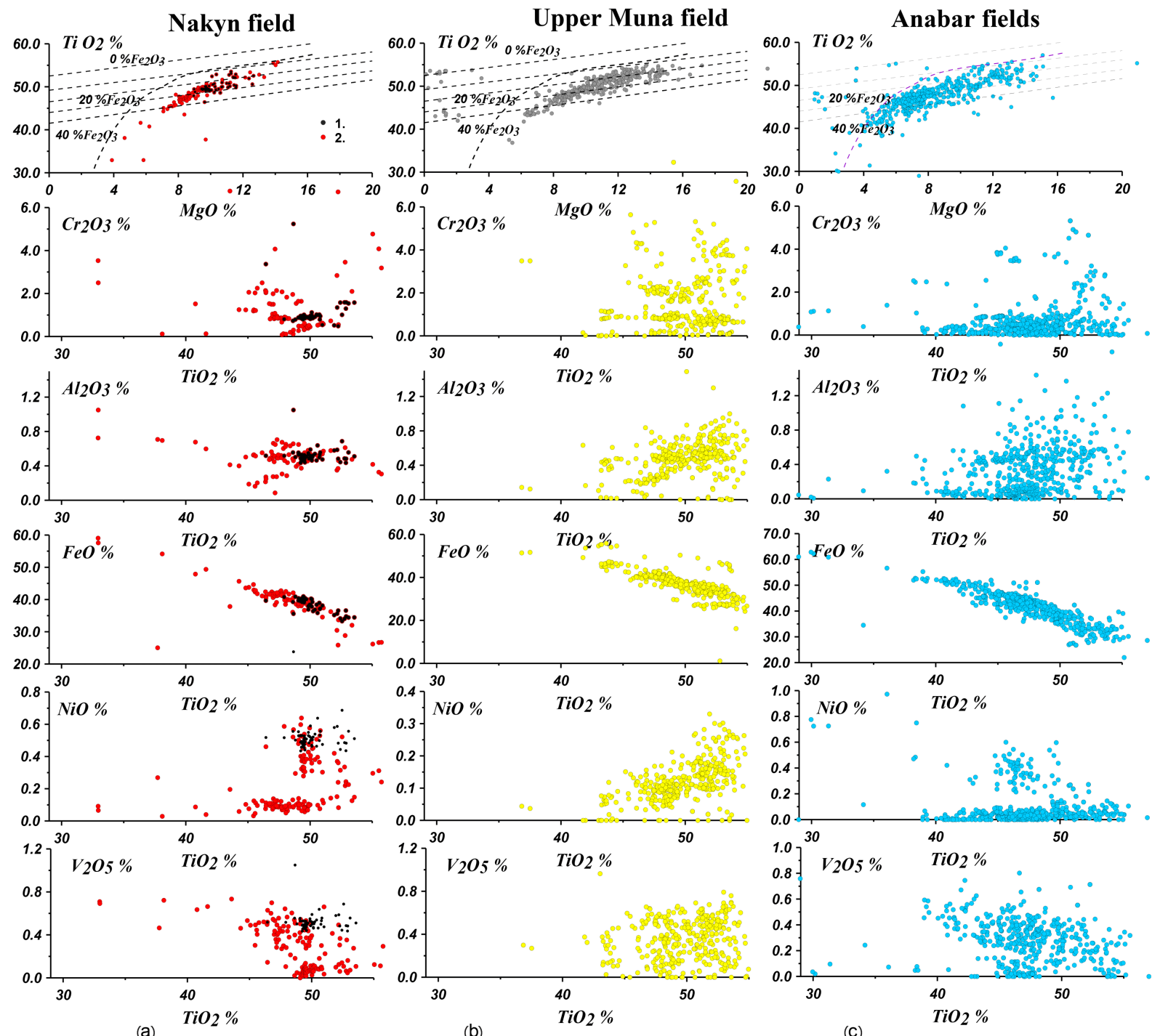

(a)

(b)

(C)

Figure 5. Variations of ilmenites from different regions within Yakutian kimberlite province (Nakyn, Upper Muna and Anabar fields). 1. Ilmenites from Nyurbinskaya pipe. 2. Ilmenites from placer.

gives good agreement with the observed values in xenoliths. Substitution of these values in the Ol-Ilm thermometer (Taylor et al., 1998) shows not a bad correlation with estimates based on clinopyroxene (Nimis and Taylor, 2000; Ashchepkov et al., 2010) thermometers (Fig. 7a). Comparison of calculated Fe\#Ol for olivine coexisting with the ilmenites and silicate minerals yields realistic values for most of the PTXfO2 diagrams (Fig. 9-11) (Ashchepkov et al., 2010).

Evaluation of the single grain thermobarometry for olivine (De Hoog et al., 2010) shows that, if the concentration of an element in one of the minerals is negligible compared to the variation in the other mineral, the equation simplifies to

$P=T \times\left(a-\ln C^{i}\right)-b$,

where $C^{i}$ is concentration of trace elements. The $-\ln C^{i}$ is positive for minor components. But for major components forming the crystal structure as Ti the logarithmic equation may be simplified.

Close linear correlations are found between the cell sizes and experimental pressures (Fig. 7b) (Reynard et al., 1996; Karki et al., 2000) (Fig. 8). Rutile has a significantly lower size cell unit (Liu, 1975) than ilmenite. Many ilmenites have exsolutions of rutile in natural assemblages (Ashchepkov et al., 2001) and experimental products (Bataleva et al., 2012). Admixture of rutile suggests significant reduction in linear correlation with pressure in this exchange. The simplified equation is

$P=A \mathrm{Ti}+B T^{\mathrm{o}}+C$,

where $B$ includes corrections to $\mathrm{Mg}$ and $\mathrm{Cr}$. These corrections were found using compositions minerals in the 


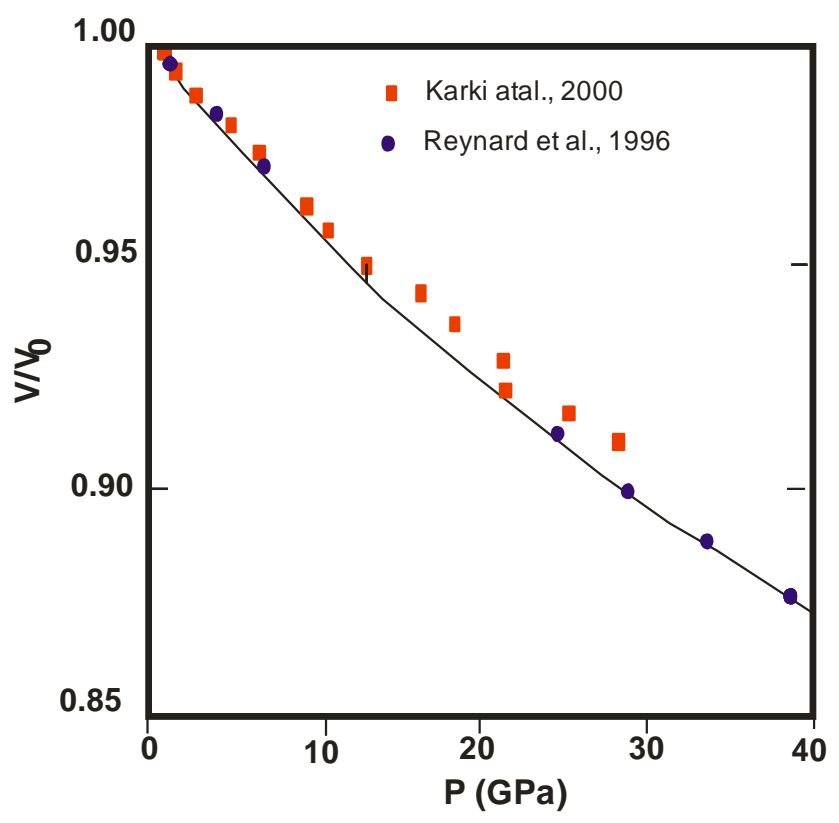

Figure 6. Correlations between the compression of unit cell volumes V/Vo in ilmenite structure vs pressure (Karki et al., 2000; Reynard et al., 1996).

xenoliths with ilmenites varying in $\mathrm{Cr}$ and xenocrysts with zonal cores in rims.

Pressure estimates were produced with clinopyroxene thermobarometry (Ashchepkov, 2003; Ashchepkov et al., 2010; Nimis and Taylor, 2000) for 110 ilmenite-bearing associations (Reimers, 1994; Alymova, 2006; Ashchepkov, 2006b; Ashchepkov et al., 2010). Ilmenites often are not in complete equilibrium with all minerals in associations. We selected mainly analyses from closely located Ilm and Cpx. Best agreement between pressure estimates based on Cpx and Ilm was obtained for the peridotite xenoliths from Sytykanskaya pipe. The approximation allowed us to calibrate the barometer as follows:

$$
\begin{aligned}
& P_{0}=\left(\mathrm{TiO}_{2}-23.5\right) 2.15-\left(T^{\circ} \mathrm{K}-750\right) / 20 . \times \mathrm{MgO} \\
& \quad \times \mathrm{Cr}_{2} \mathrm{O}_{3}-1.45 \times \mathrm{MnO} \times T^{\circ} \mathrm{K} / 1273 \\
& -0.01 \times T^{\circ} \mathrm{K}(P-1)
\end{aligned}
$$

and yielded further corrections

$P_{1}=P_{0}+\left(60-P_{0}\right) / 6.2$

and next

$$
P_{2}=P_{1}+(35.4-\mathrm{FeO}) / 0.9+(0.20-\mathrm{Fe} /(\mathrm{Fe}+\mathrm{Mg})) \times 0.1 \times P_{1}
$$

(all components are in wt $\%$ and $P$ in kbar). This yields a better agreement than the previous version (Ashchepkov et al., 2010). Nearly linear correlation of pressure between clinopyroxene and ilmenite estimates (using the same temperatures) was found within 7.0-3.5 GPa interval (Fig. 7b). This equation is calibrated for the associations crystallized in $\mathrm{Mg}$-rich protokimberlite melts and peridotite rocks.

Checking this thermobarometric method for the large amount of kimberlitic concentrates and xenoliths from Yakutia and worldwide kimberlites (Ashchepkov et al., 2010, 2012, 2013a, b, c; Afanasiev et al., 2013) shows good agreement of the ilmenite PT parameter with those produced by the orthopyroxene (McGregor, 1974), clinopyroxene (Nimis and Taylor, 2000) and Opx-Gar thermobarometric methods for mantle peridotites (Brey and Kohler, 1990; Nickel and Green, 1985).

The equation derived from the correlation with pressure values based on clinopyroxenes using the database for xenoliths from Mir and Udachnaya pipes (Alymova, 2006), data for xenoliths from the Sytykanskaya pipe (Reimers, 1994; Reimers et al., 1998; Ashchepkov et al., 2014, submitted) and the Dalnyaya pipe (Rodionov et al., 1988, 1991), yielded good agreement for the pressure using the same temperatures (Figs. 11-12). The correlations between the methods of mineral thermobarometry and PT diagrams based on pyroxenes and ilmenites show good agreement (Fig. 9b).

According to $\mathrm{FeO} / \mathrm{Fe}_{2} \mathrm{O}_{3}$ ratios (Green and Sobolev, 1975; Wyatt et al., 2004) and calculations using the IlmOl oxybarometer (Taylor et al., 1998), the degree of oxidation varies from -3 to $+1 \Delta \log$ QMF (quartz-magnetitefayalite) buffer and becomes positive for Fe-rich ilmenites (Nikolenko and Afanasiev, 2010). The values for megacrystalline ilmenite are higher than the diamond stability field (McCammon et al., 1998; McCammon and Kopylova, 2004; Kadik et al., 1989) and are close to the EMOG/D buffer (Stagno and Frost, 2010). Similar values above QMF are given by ilmenite-rutile oxygen barometry (Zhao et al., 1999): for the megacryst with the ilmnites exsolving rutiles.

We calculated the oxygen fugacity values using the monomineral versions of the ilmenite-olivine, spinel-olivine (Taylor et al., 1998) and garnet (Gudmundsson and Wood, 1995) oxybarometers and corrected equations for clinopyroxene (Ashchepkov et al., 2012).

\section{Regularities of the distribution of ilmenite associations in the mantle sections worldwide}

The conditions obtained from pyroxene thermobarometry for ilmenite-bearing associations shown on the PT diagram (Fig. 8) reveal a similarity with those produced by ilmenite PT equations. The highest pressure (7.0-6.0 GPa) estimates for the HT pyroxenites and eclogites (Boyd and Nixon, 1973) trace the convective branch of the geotherm corresponding to deformed garnet peridotites (Boyd et al., 1997). PT conditions for hybrid pyroxenites and HT metasomatic and MARID-type xenoliths (Dawson and Smith, 1977; Hamilton et al., 1998; Gregoire et al., 2002) plot within the transition 


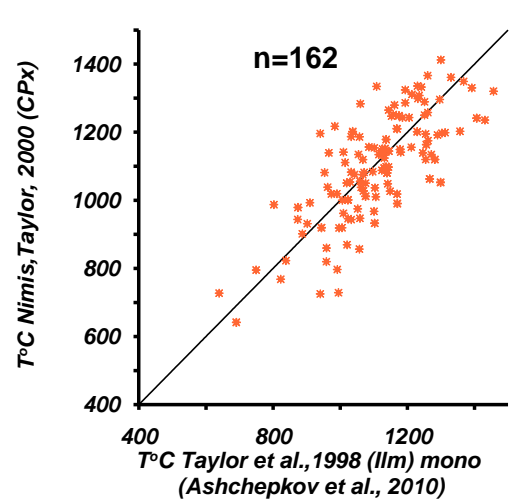

(a)

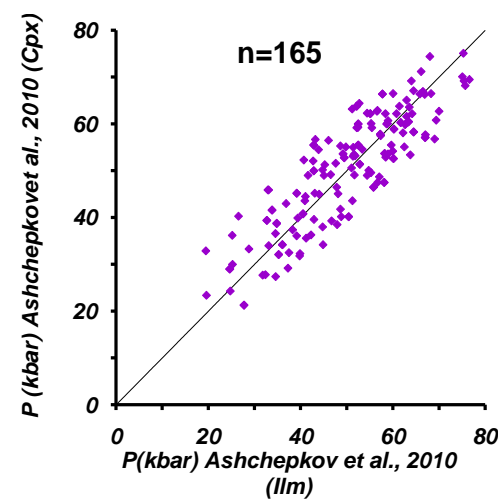

(b)

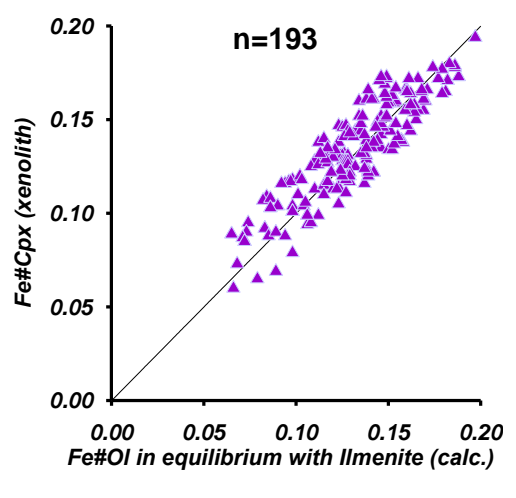

(c)

Figure 7. Correlations of pressure (a), temperature (b) and calculated Fe\#Ol for ilmenites and clinopyroxenes (Ashchepkov, 2010) from the same associations.

between the SCLM base and lithospheric mantle (5.5 to $6.5 \mathrm{GPa}$ ),

Commonly PT clusters for Ilm-bearing metasomatic veins and megacrysts in the lower part of lithospheric mantle columns coincide in pressure but differ in temperature and Fe\# of coexisting Ol (Figs. 9-11).

\section{Thermobarometry of ilmenite associations for mantle columns beneath Siberian kimberlite pipes}

Enhanced calibrations of the thermobarometric equations for clinopyroxenes and garnets as well as for ilmenites highlight the sharp layering of mantle sequences and yield realistic arrays for the peridotite, pyroxenite and subcalcic garnets. They also show the positions of the megacrystalline series, pyroxenites and metasomatites in PT diagrams (Ashchepkov et al., 2010, 2012, 2013a, b, c) for xenoliths from Udachnaya (Boyd et al., 1997; Kuligin, 1997; Pokhilenko et al., 1999; Alymova, 2006; Pokhilenko, 2006; Ionov et al., 2010; Doucet et al., 2013), Mir (Beard et al., 1996; Roden et al., 2006; Logvinova et al., 2008), Sytykanskaya and other Yakutian pipes (Reimers et al., 1998; Alymova, 2006; Ashchepkov, 2010).

PT conditions for megacrystalline ilmenites from Udachnaya trace an advective PT path rising along the $40 \mathrm{~m} \mathrm{Wm}^{-2}$ geotherm from the SCLM base at $7.5 \mathrm{GPa}$ to the boundary between the lower and upper parts of the SCLM at 4.0-3.5 GPa (Ashchepkov et al., 2010) (Fig. 11a). This PT path generally coincides with the HT PT estimates for some sheared and porphyroclastic peridotites obtained from polymineral (Brey and Kohler, 1990) and monomineral clinopyroxene thermobarometry. It is close to the PT conditions for HT eclogites and chromite inclusions in diamonds (Logvinova et al., 2005). PT estimates for ilmenite-bearing pyroxenites and peridotites together create lines of nearly equal pressures covering the range of heating from 35 to $45 \mathrm{~m} \mathrm{Wm}^{-2}$ in PT and $\mathrm{PFe} \# \mathrm{Ol}$ diagrams (Fig. 11a) at 5.0

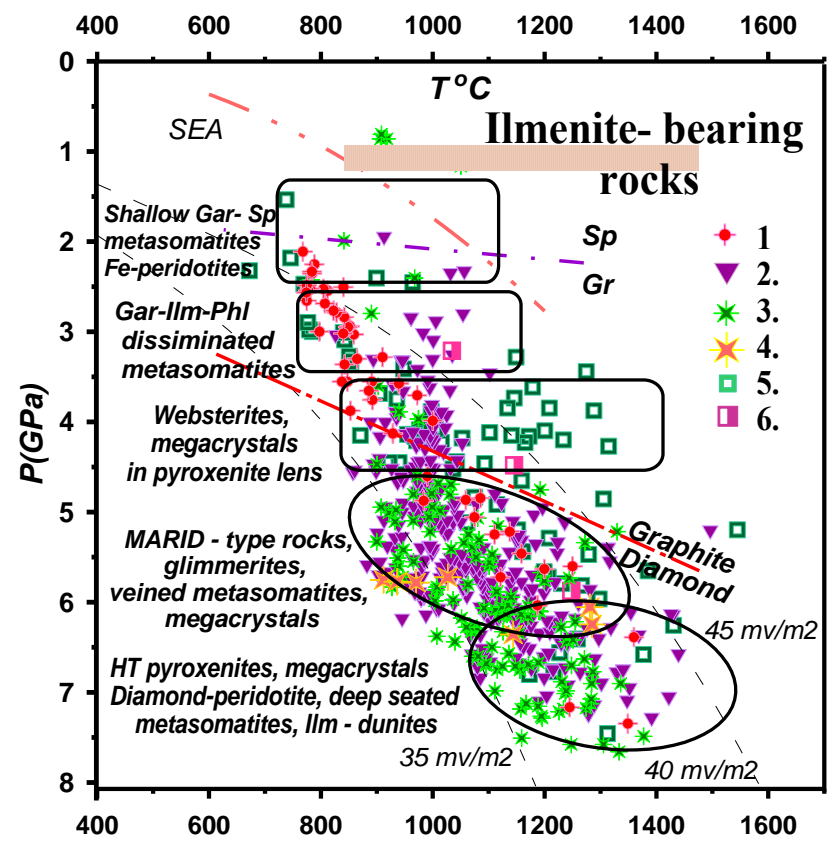

Figure 8. PT diagram for kimberlitic ilmenites and silicate minerals from ilmenite-bearing xenoliths and xenocrysts intergrowths. 1 . Garnet thermobarometry for peridotites and pyroxenites (Ashchepkov, 2010a); 2. Ilmenite thermobarometry (Ashchepkov et al., 2000) for the xenoliths with ilmenites associations; 3. Clinopyroxene thermobarometry: according to $T{ }^{\circ} \mathrm{C}$ (Nimis and Taylor, 2000) - P (GPa) (Ashchepkov, 2003); 4. Clinopyroxene thermobarometry (Nimis and Taylor, 2000); 5. Orthopyroxenes thermobarometry (Brey and Kohler, 1990) - (McGregor, 1974); and 6. Ilmenite thermobarometry (Ashchepkov et al., 2010).

and 5.5 GPa. The HT pyroxenites with ilmenites occur more frequently at pressures near 6.0-7.0 GPa, corresponding to the inflection in the pyroxene geotherm found for deformed peridotites (Boyd et al., 1997; Agashev et al., 2013) and for the positions of eclogites. 
(a)
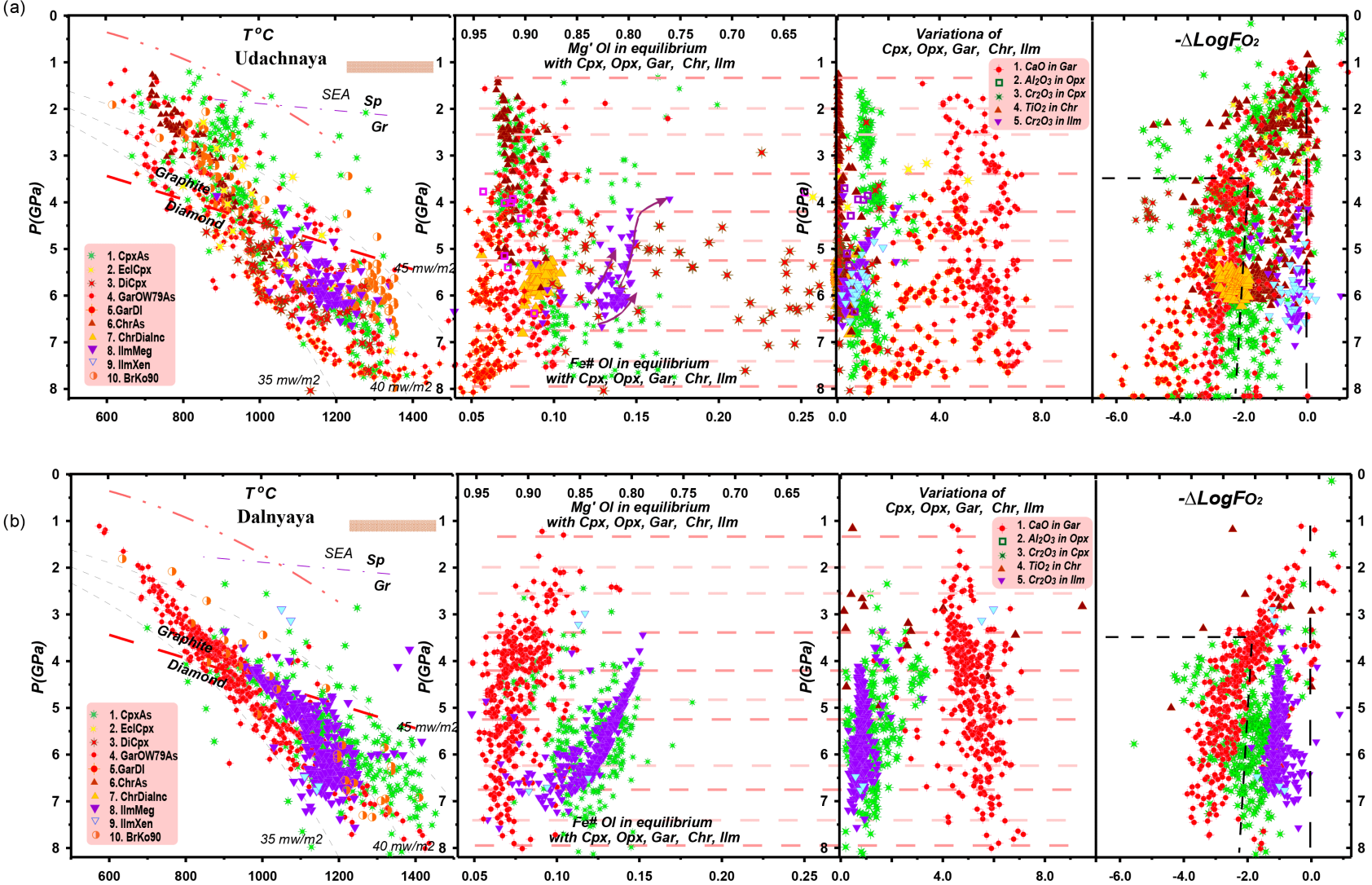

Figure 9. (a) $\mathrm{PTXfO}_{2}$ estimates for the minerals from xenocrysts and xenoliths from Udachnaya pipe, Daldyn field. Fe\# is calculated Fe number of olivines, coexisting with garnets, pyroxenes chromite and ilmenites. 1. Clinopyroxene thermobarometry $\mathrm{T}^{\circ} \mathrm{C}(\mathrm{Nimis}$ and Taylor, 2000) - P (GPa) (Ashchepkov, 2003) for xenoliths (Boyd et al., 1997; Pokhilenko et al., 2000; Malygina, 2005; Pokhilenko et al., 2007 ); 2. The same for common eclogites; 3. The same for diamond inclusions (Beard et al., 1996; Snyder et al., 1997; Taylor et al., 2003; Sobolev et al., 1997, 2003, 2004; Logvinova et al., 2005); 4. Garnet thermobarometry: $T{ }^{\circ} \mathrm{C}$ (O’Neil, Wood, 1979 monomineral) - $P$ (GPa) (Ashchepkov, $2010 ; 12) ; 5$. The same for diamond inclusions; 6 . Cr-spinel thermobarometry: $T{ }^{\circ} \mathrm{C}$ (Taylor et al., 1998) - $P$ (GPa) (Ashchepkov et al, 2010); 7. The same for diamond inclusions; 8 . Ilmenite thermobarometry: $T{ }^{\circ} \mathrm{C}$ (Taylor et al., 1998) $-P$ (GPa) (Ashchepkov et al., 2006) for grains from heavy mineral separates; 9. The same for ilmenites from xenoliths (Alymova, 2006); 10. Brey and Kohler (1990). Line of diamond-graphite boundary after (Kennedy and Kennedy, 1976). (b) $\mathrm{PTXfO}_{2}$ estimates for minerals from xenocrysts and xenoliths from Dalnyaya pipe. Symbols are the same as for (a).

On the P vs. Fe\#Ol diagram (Fig. 9a), calculated variations for Fe\# for the megacrysts increase from 0.1 to 0.15 in the 7.0-4.0 GPa pressure interval, partly coinciding with the Fo content for $\mathrm{Cpx}$ and $\mathrm{Ol}$ intergrowths with ilmenites, whereas the Fe lherzolite xenoliths and pyroxenites with Ilm (Alymova, 2006; Alymova et al., 2008; Solov'eva et al., 2008) correspond to the lower values of $\mathrm{Fe \# Ol} \mathrm{(0.1-0.12).} \mathrm{The} \mathrm{low-}$ est Fe\# values of $0.05-0.06$ are found in harzburgites and the most depleted diamond-bearing associations (Pokhilenko et al., 1976).

New data for the Dalnyaya pipe based mostly on mantle xenoliths (> 110) (Ashchepkov et al., 2013) and for concentrates as well as previous data for pyroxenites (Rodionov et al., 1988, 1991; Alymova, 2006) give the deepest and highest temperature plot of the mantle section in Yakutia (Fig. 9b). Estimates for porphyroclastic and sheared peridotites in $7-$
$5 \mathrm{GPa}$ interval are overlapped by the PT values for ilmenites. Ilm megapyroxenites sometimes with garnet (Rodionov et al., 1988) are lower temperature. Metasomatic peridotites with Cr-bearing ilmenites close in Fe\# to common garnets $(0.8-0.11)$ are located in three SCLM levels and correspond to the $45 \mathrm{~m} \mathrm{Wm}^{-2}$ geotherm.

In the PT diagram for the SCLM beneath the Mir pipe (Fig. 12a), the PT values for ilmenite megacrysts also trace a HT $39-45 \mathrm{~m} \mathrm{Wm}^{-2}$ from 7.0 to $2.0 \mathrm{GPa}$. The inflection of geotherm called the convective branch (Boyd, 1973; Boyd et al., 1997) at 7.0 to $6.0 \mathrm{GPa}$ is traced by ilmenites which overprint the PT conditions for the Fe-enriched minerals. Nearer 4.0 GPa, the geotherm splits and ilmenites trace the HT PT advective arrays close to PT conditions of clinopyroxenes from pyroxenites. The long stepped HT PT path refer to megacrysts geotherm (Eggler and Mccallum, 1976) 

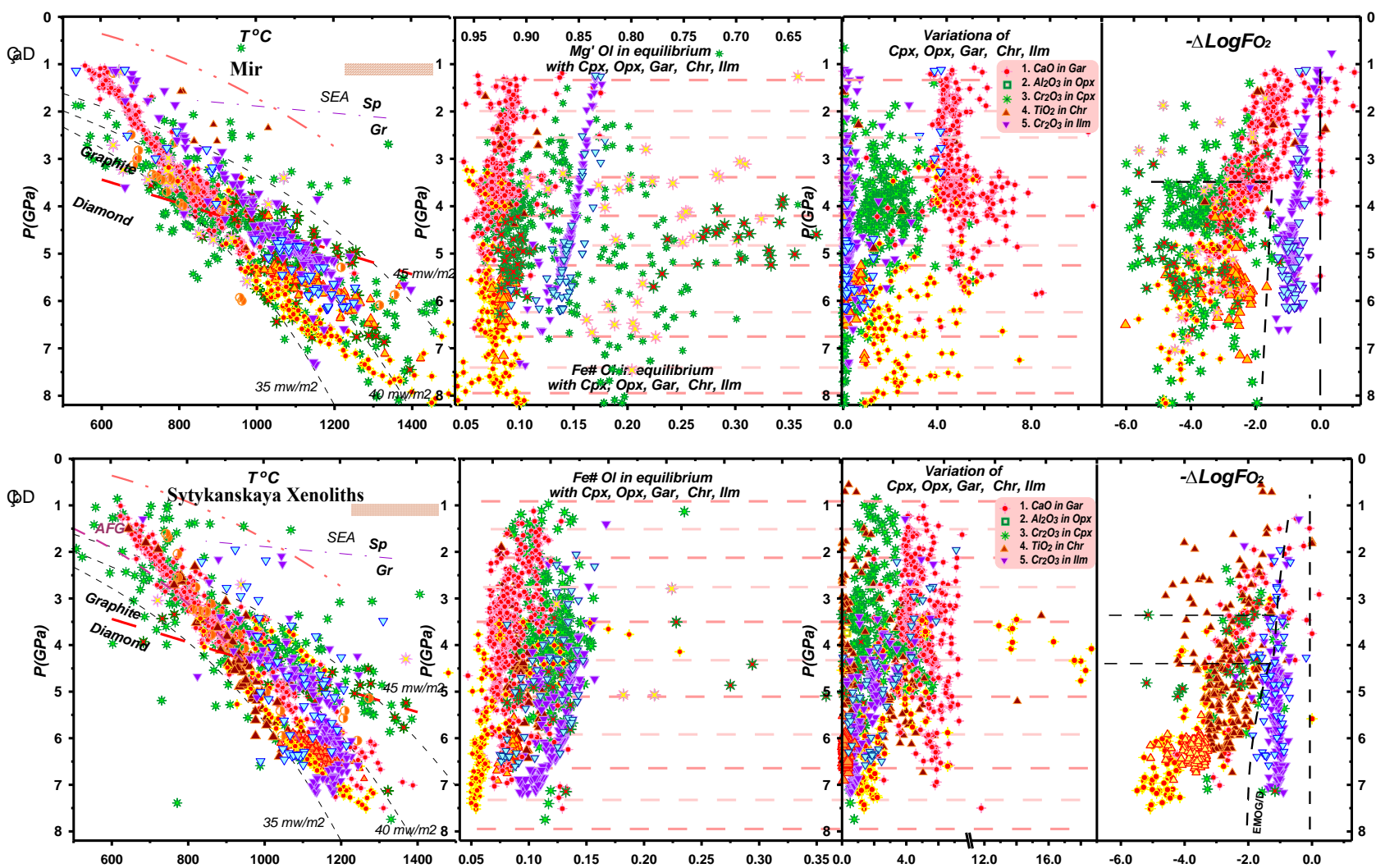

Figure 10. (a) $\mathrm{PTXfO}_{2}$ estimates for minerals from xenocrysts and xenoliths from the Mir pipe. Symbols are the same as for Fig. 9a. (b) PT estimates for the minerals from xenocrysts and xenoliths from the Sytykanskaya pipe and variations of the Fe\# for coexisting olivines vs. pressure estimates obtained with monomineral thermobarometry. Symbols are the same as for Fig. 9a.

but several estimates in the lower part for the pyroxenites are close to the $37 \mathrm{~m} \mathrm{Wm}^{-2}$ low temperature (LT) geotherm. Symplectites with pyroxenes are found in the lower part of the convective branch.

In the PFe\#Ol diagram (Fig. 10a), the values for garnets, chromites and ilmenites form fluctuating lines, possibly reflecting primary layering of the SCLM formed by paleosubduction slabs (Pearson et al., 2003). The clots of ilmenite PT estimates may trace the boundaries of the primary layering. There are at least three $\mathrm{PFe \# Ol} \mathrm{arrays.} \mathrm{The} \mathrm{lower} \mathrm{Fe \#}$ values refer to the contact zones of megacrystalline associations while the middle one corresponds to the common megacrysts. The most Fe-rich array is for ilmenite megapyroxenites. Cr-bearing metasomatic associations are found in the 3-5 GPa interval.

PT estimates for minerals from concentrates and xenoliths from the Sytykanskaya pipe (Fig. 10b) can be used to reconstruct the SCLM section in the northern part of the Alakit region. The PT paths for ilmenite megacrysts create a stepped trend divided into three parts: two broad clusters at the base of the SCLM (7.0-6.5 GPa) and in the 5.0-3.0 GPa pressure interval, and a narrower chain connecting them. A broad scatter of the calculated $\mathrm{Fe \# Ol}$ values is typical for the upper part near 4.0 GPa where the dense cluster suggests a large propor- tion of metasomatic veins (Reimers et al., 1998; Ashchepkov et al., 2010). The increase in $\mathrm{Fe} \#$ and $\mathrm{Cr}$ for the ilmenites from the bottom to the upper part of the mantle section is typical for most of mantle sections beneath this kimberlite and most pipes in Yakutia especially in the Alakit field (Ashchepkov et al., 2010). The abrupt increase of $\mathrm{Cr}$ and decrease of Fe\# near $3.5 \mathrm{GPa}$ and above in the mantle section corresponds to ilmenite crystallization mainly within metasomatic veins forming dense stockworks as seen in xenoliths. The ilmenite-bearing xenoliths with the veinlets of Ilm and Cpx are widespread, mainly in the middle part of the mantle column.

PT values for ilmenites from the three kimberlite phases found in the Yubileinaya pipe quarry, i.e., autholithic kimberlite (Kurszlaukis et al., 2008; Zinchuck and Koptil, 2008), the Ozernaya pipe, Ottorzhenets kimberlite body and the Aprelskaya pipe represent four stages of kimberlite activity (Fig. 11a, b; Supplement 4, Fig. 3a, b). Ilmenites in heavy mineral fractions from the autholithic kimberlite show the deepest $(\sim 7.5 \mathrm{GPa})$ and relatively HT conditions. The highest temperature values at the base of the SCLM correspond to a geothermal gradient of $43 \mathrm{~m} \mathrm{Wm}^{-2}$ with deviations to the $35 \mathrm{~m} \mathrm{Wm}^{-2}$ conductive geotherm. The continuous increase of $\mathrm{Cr}$ with decreasing pressure suggests continuous 

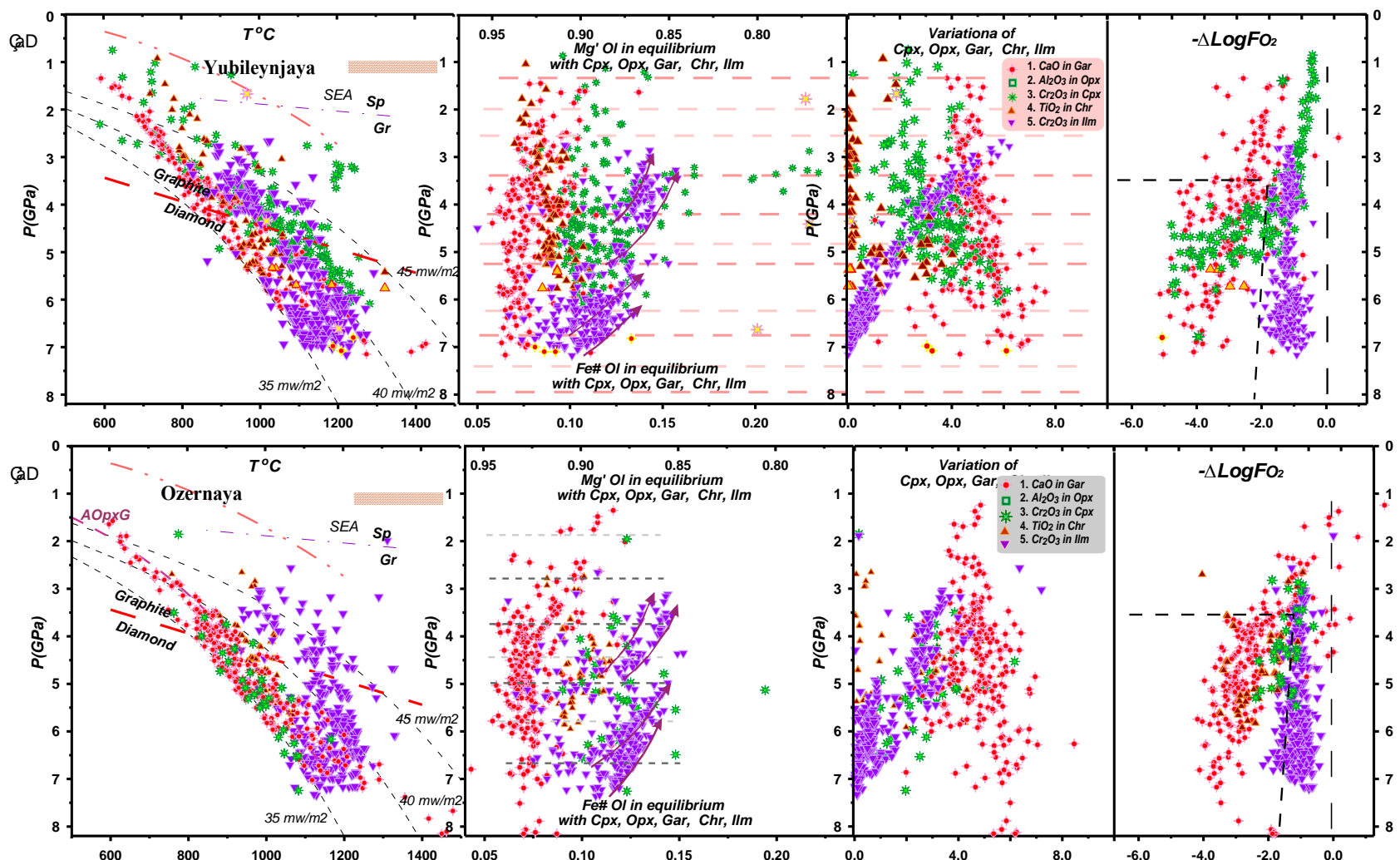

Figure 11. (a) $\mathrm{PTXfO}_{2}$ estimates for minerals from the Yubileynaya pipe. Symbols are the same as for Fig. 9a. (b) PTXfO 2 estimates for minerals from the Ozernaya pipe. Symbols are the same as for Fig. 9a.

contamination of rising melts. But several (4) separate lines of $\mathrm{PFe} \# \mathrm{Ol}$ and increasing of $f \mathrm{O}_{2}$ in three levels may refer to the crystallization in semi-closed magmatic systems.

PT estimates for the Ozernaya mantle column (Fig. 11b) also reveal that the base of the SCLM is situated at 7.5 GPa. A wide scatter of temperature estimates between the 35 and $45 \mathrm{~m} \mathrm{Wm}^{-2}$ geotherms which is close to those of the $\mathrm{Fe}$ enriched Cpx corresponds to the veined metasomatities. The ilmenite PT clusters are located at 7.5-5.5 GPa and around $4.5 \mathrm{GPa}$.

\section{Trace element geochemistry of ilmenite megacrysts}

The LAM ICP-MS study of ilmenite compositions (Ashchepkov et al., 2008b) reveals three main groups (Figs. 12-13). The first one (group 1) has low rare earth element (REE) concentrations and flatter, spoon-like or complex curved REE patterns. They have high peaks for Ta and $\mathrm{Nb}$ and slightly lower in $\mathrm{Zr}$ and $\mathrm{Hf}$, similar to those for ilmenites from South Africa (Dawson et al., 2001; Gregoire et al., 2003). The $\mathrm{Pb}$ peaks are their characteristic feature. For the second group (gr2), inclined linear REE ( $\mathrm{La} / \mathrm{Yb}_{n}$ $\sim 10-15)$ patterns similar for those of alkali basaltic melts and temperate peaks of high-field-strength elements (HFSE) are typical. The last group (group 3) is highly enriched in REE and other trace elements revealing smoother trace element diagrams with HFSE peaks. The multi-element diagrams are generally similar for different pipes, showing peaks in $\mathrm{TaNb}$ and $\mathrm{ZrHf}$ and fluctuating $\mathrm{Pb}$ anomalies which are positive due to melting processes and negative for fractionation.

In Udachnaya group 1 ilmenites are abundant (Fig. 12a), with compositions of REE (0.1/C1) forming a series of patterns from spoon-like to flatter slightly REE-enriched patterns. Very high TaNb peaks are in contrast to low REE concentrations. Ilmenites from the Dalnyaya pipe have the lowest REE content and close to W-shaped REE patterns (Fig. 12b). Small negative Y anomalies were found only in ilmenites from Dalnyaya pipes. Ilmenites from the Festivalnaya pipe (Fig. 12c) also show inclined $\mathrm{La}--\mathrm{Yb}_{n}$ patterns, possibly produced by partial melting. The high Hf peak relative to $\mathrm{Zr}$, as well as enrichment of $\mathrm{Ba}$ and $\mathrm{Th}$ found in some of these compositions, are unusual for ilmenites from the other pipes.

In Alakite, field ilmenites from the Aykhal pipe (group 1) show slightly inclined REE patterns for the most Ti-rich (deepest) samples (Fig. 13a). Ilmenites from the Komsomolskaya pipe have $\mathrm{W}$-shaped inclined REE patterns with an inflection at $\mathrm{Gd}$ and a peak at $\mathrm{Pb}$ (Fig. 13b). The mildly enriched group $\sim 100$ relative to $\mathrm{PM}$ primitive mantle 

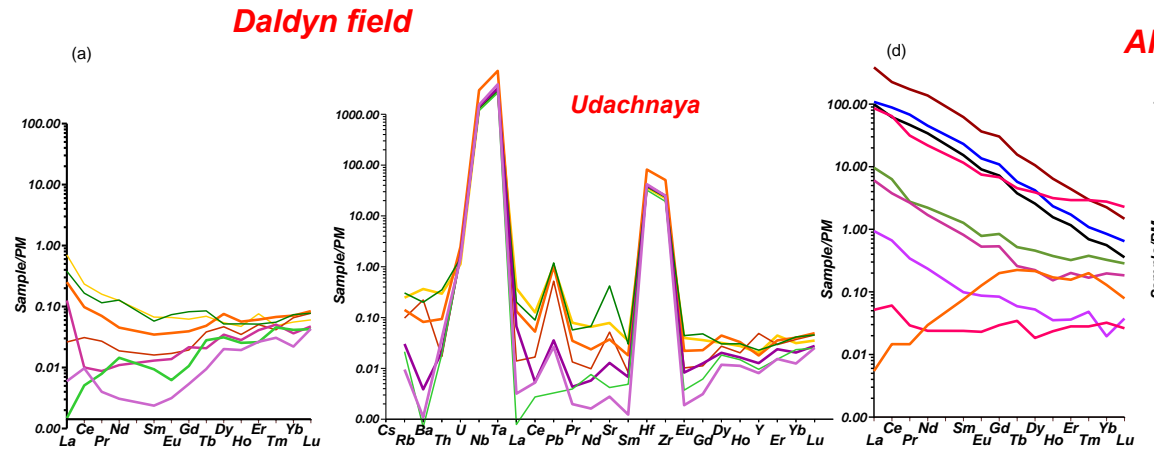

Alakite field
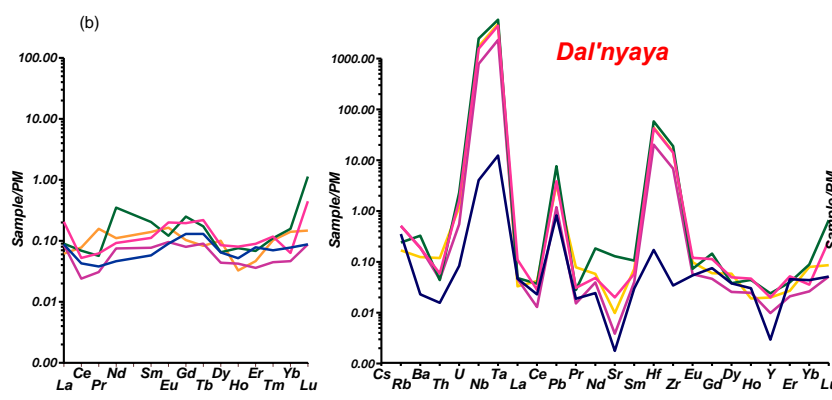

(e)
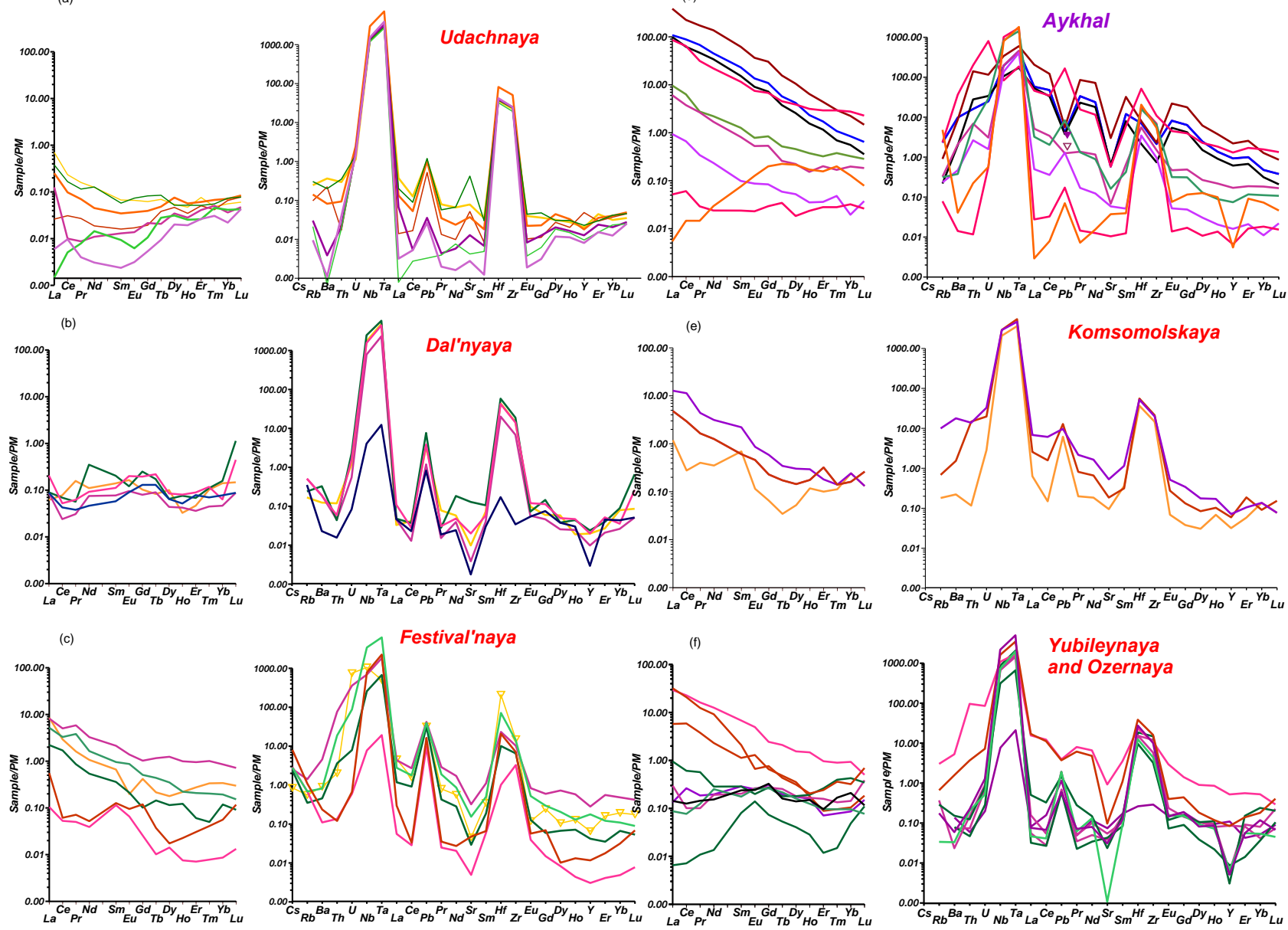

Figure 12. (a) REE and trace element spider diagrams for ilmenites from heavy mineral separates from Daldyn field kimberlites (a Udachnaya, b Dalnyaya and c Festival'naya pipes) and from Alakit field kimberlites (d Aykhal, e Komsomolskaya, f Yubileinaya and Ozernaya pipes).

(McDonough and Sun, 1995) (100/PM) of picroilmenites (group 2) also shows trace element patterns typical for group 2 (Fig. 15b, c, d). Ilmenites from Yubileynaya have REE patterns (Fig. 12c) that are almost S-shaped, similar to those determined for chromites.

In Malo-Botuobinsky field trace element patterns for ilmenites from Mir (group 1) 0.1 PM are flat in MHREE but vary in LREE patterns increasing together with most of the trace elements. Typical group 2 patterns are found for two ilmenites from the middle part of the mantle column. The rim of one ilmenite from Mir reveals an abrupt enrichment in trace elements resembling that of group 3 samples, while the inner core is closer to group 2 in composition (Fig. 13a). Ilmenites from the International'naya pipe show a REE pattern similar to garnets of pyroxenitic type with a hump in MHREE. Trace element diagrams reveal Y minima typical for low-Ca garnets (Stachel et al., 2008) and Siberian diamonds (Afanasiev et al., 2005) that show signs of depletion of the melt source. One ilmenite has a small minimum at Eu (Fig. 13b).

In the Nakynsky region (Fig. 13c) most of the highpressure ilmenite (group 1) show flat REE patterns with gentle minima in MHREE and fluctuations in LREE especially in Ce. The enriched (gr2) varieties demonstrate inclined linear trace element patterns similar to those of alkali basalts. In Prianabarie all three populations of analyzed ilmenites show different trace element patterns in the different pipes (Fig. 13d). Ilmenites from the Trudovaya pipe (Fig. 13d) demonstrate different types of trace element patterns like those from Aykhal pipe. Ilmenites having the REE level near 1/PM display slightly inclined distributions with $\mathrm{Pb}$ peaks and a mild enrichment in $\mathrm{ZrHf}$ and $\mathrm{TaNb}$. Ilmenites with REE levels $\sim 100 / \mathrm{C} 1$ (for La) demonstrate an inclination of the REE patterns close to primitive $1 \%$ melts produced in garnet-facies peridotites (McDonough and Sun, 1995). The 
Malo-Botuobinsky field

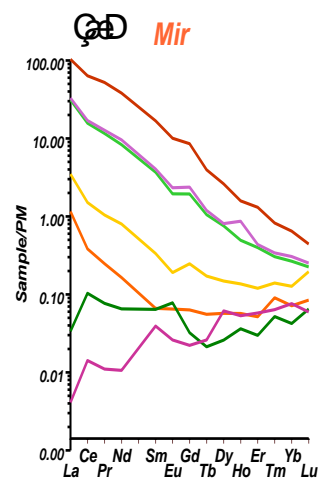

b

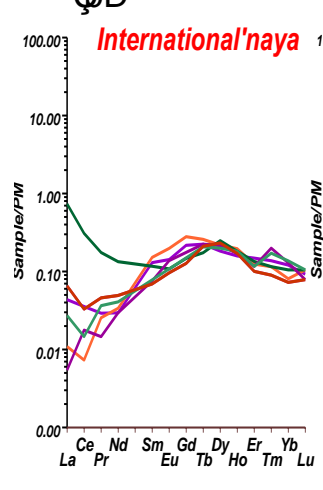

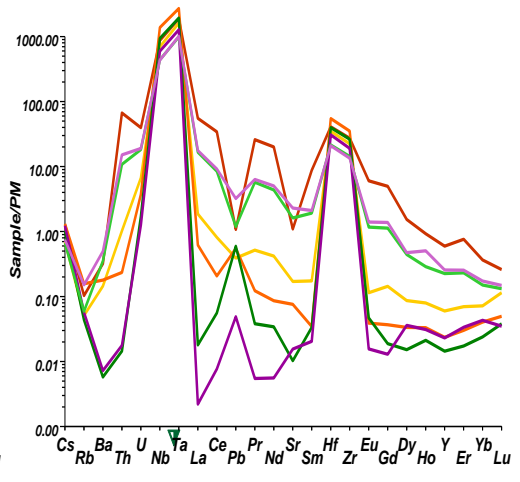

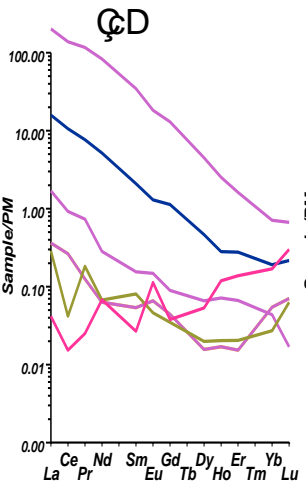

d
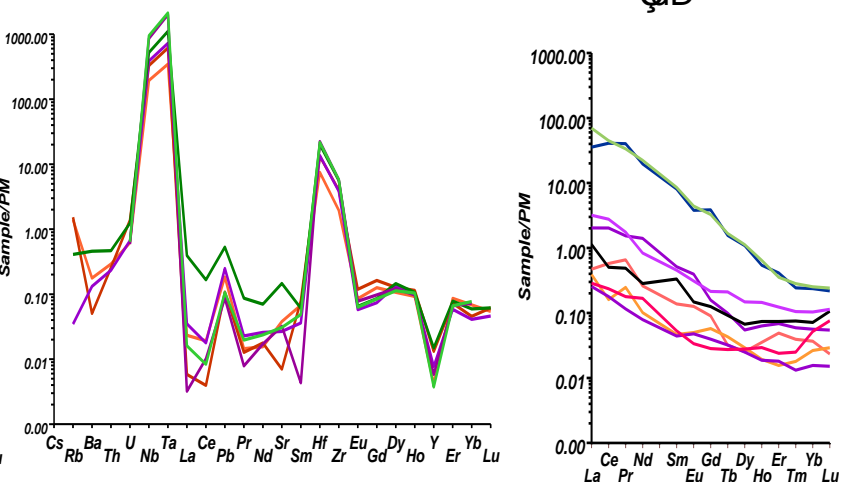

Nakynsky field

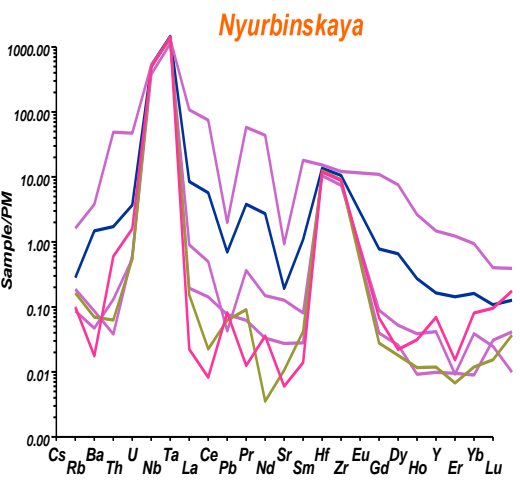

Anabar fields
Trudovaya

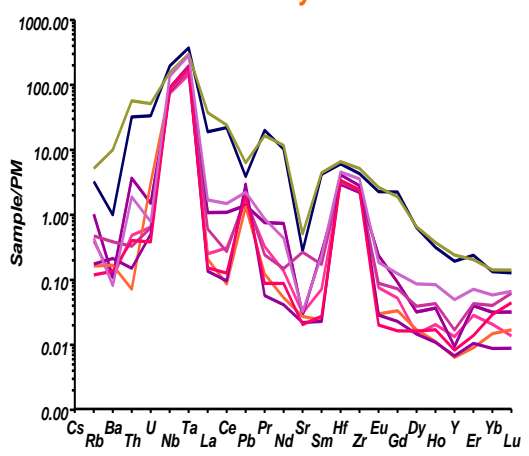

Figure 13. (a) REE patterns and trace element spider diagrams for ilmenites from heavy mineral separates from kimberlites from the MaloBotuobinsky (a Mir and b International'naya pipes), Nakynsky field (c Nyurbinskaya pipe) and Anabar kimberlites (d Trudovaya pipe).

most enriched ilmenites show enrichment up to 1000/C1 for La have $\mathrm{La} / \mathrm{Yb}_{n} \sim 15$. They show no HfZr anomalies.

\section{Discussion}

\subsection{Model of origin based on PT estimates}

The suggestion about the origin of ilmenites at the base of the SCLM (Boyd and Nixon, 1973) from protokimberlites was supported by Gurney et al. (1979) for ilmenites from the Monastery pipe based mainly on the PT estimates for Ilm-Opx symplectites and by the contact relationships with sheared peridotites (Moore and Lock, 2002). A similar model (Moore et al., 1992) suggested that they are products of extensive fractionation in pegmatite-like bodies, which is supported by evidence of fluid crystallization (Kopylova et al., 2009) for megacrystalline ilmenites. Direct calculations for clinopyroxenes coexisting with ilmenites (Dawson and Reid, 1970; Haggerty et al., 1979; Haggerty, 1995; Gurney et al., 1979,1998 ) and orthopyroxenes from ilmenite intergrowths and from quenched nodules (Rowlinson and Dawson, 1979) including clinopyroxenes in type II diamond (Moore, 2009) give a pressure interval from 6.0 to $4.0 \mathrm{GPa}$. Estimation of a HT geotherm based on megacrysts (Eggler and Mccallum, 1976) was followed by the suggestion that megacrysts result from polybaric magma fractionation (Neal and Davidson, 1989; Eggler and Mccallum, 1976) during crystallization of fluid-rich magma. Ilmenite trends from many localities show the gap in the trends between the Mg-rich and Fe-rich varieties, for example in Angola (Robles-Cruz et al., 2009; Ashchepkov et al., 2012).

The highest temperature metasomatites show depths of origin near 4.0-7.5 GPa. This coincides well with the conditions determined by most thermobarometric methods and agrees well with the SCLM thickness determined by seismic methods (O'Reilly et al., 2009) near $270 \mathrm{~km}$. Inflections of the geotherms and the major field of the megacryst associations start from 7 to $6.5 \mathrm{GPa}$ and refer to the minimum on the peridotite solidus in the lower part of mantle column (redox melting) (Tappe et al., 2007) and olivine creep under the presence of volatiles (Peslier et al., 2012) and magma fracturing.

Positions of the ilmenite-bearing pyroxenites often coincide with those determined for HT eclogites, showing that 


\section{Melts in equilibrium with IImenites}
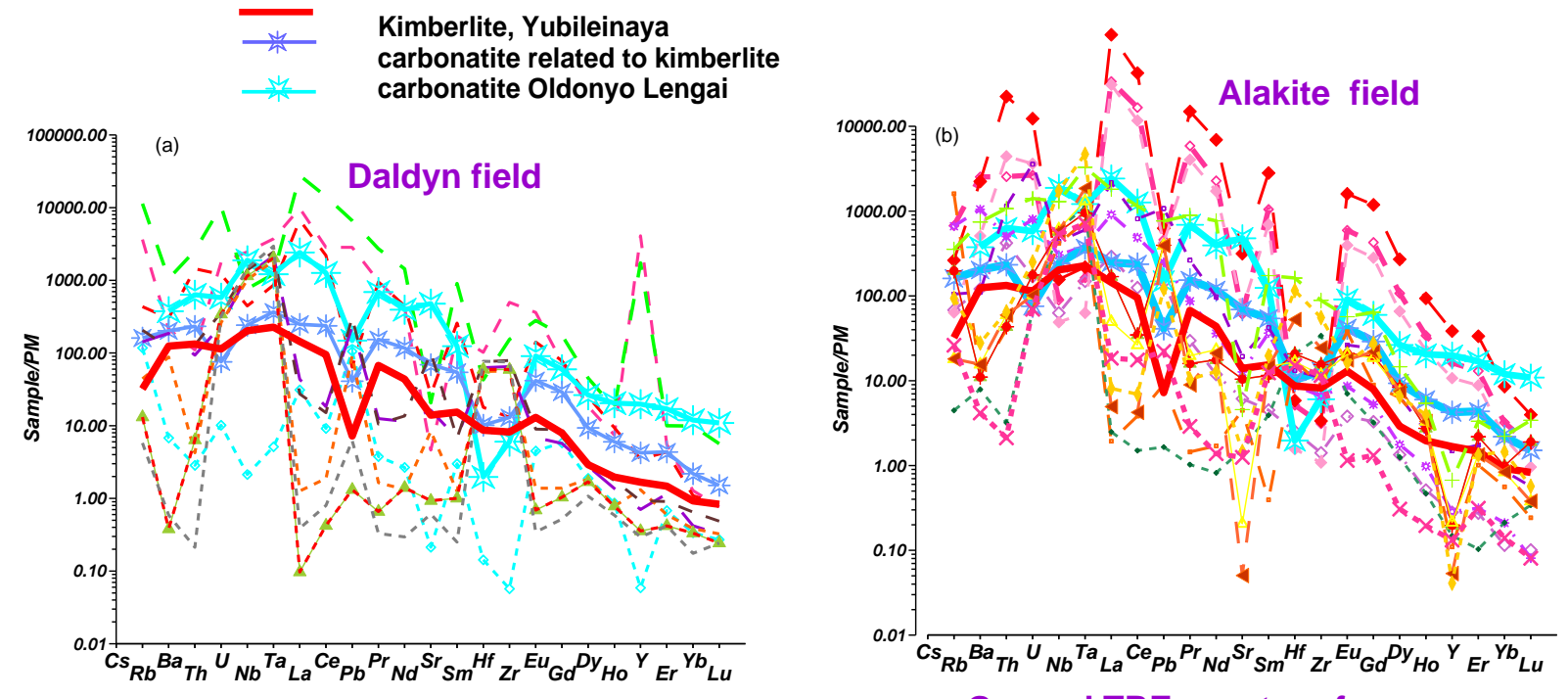

General TRE spectra of three picroilmenite groups
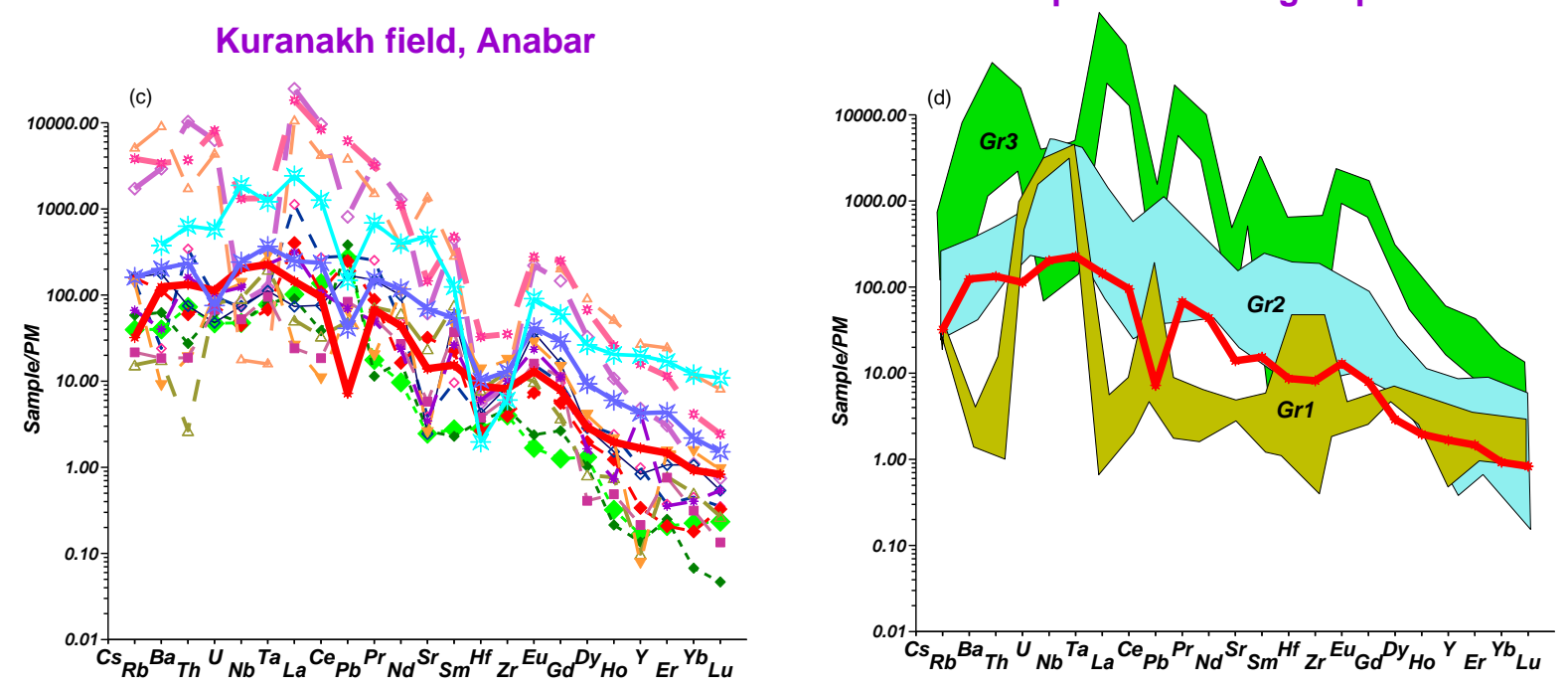

Figure 14. Trace element patterns for parental melts for the ilmenites from the different regions in Yakutia: (a) Daldyn, (b) Alakit, (c) Kuranakh field, Anabar region and (d) typical trace element patterns for three ilmenite groups. Signs: 1. Kimberlite from the Yubileynaya pipe (Kostrovitsky et al., 2007); 2. Carbonatite associated with kimberlite 3. Carbonatite from Oldoinyo Lengai (Bell and Simonetti, 1996; Bizimis et al., 2003).

they may be formed as a result of reaction between the protokimberlite melts that formed megacrysts and mantle eclogites. But mantle metasomatites which are close in pressures to the clots of the megacrysts PT points reflect refertilization events in peridotites.

\subsection{Model of fractionation and melting based on trace elements}

Geochemistry of calculated parental melts (Figs. 14 and 15) determined with the clinopyroxene (Hart and Dunn, 1993) and Ilm distribution (partition) coefficients KD (Zack and Brumm, 1998) shows that a significant amount of picroilmenites are the products of differentiation of HFSE-rich kimberlite-like melts.

Assimilation + fractional crystallization (AFC) processes (Neal and Davidson, 1989) are indicated by the $\mathrm{Cr}$ increase with decreasing pressures during crystallization on the wall of large channels and intermediate chambers accompanied by peridotite assimilation (DePaolo, 1981). Cr-poor ilmenites (Moore and Belousova, 2005) are found mainly in the lower part of mantle section but in some pipes, such as 
Parental melts for coexisting ilmenites and clinopyroxenes
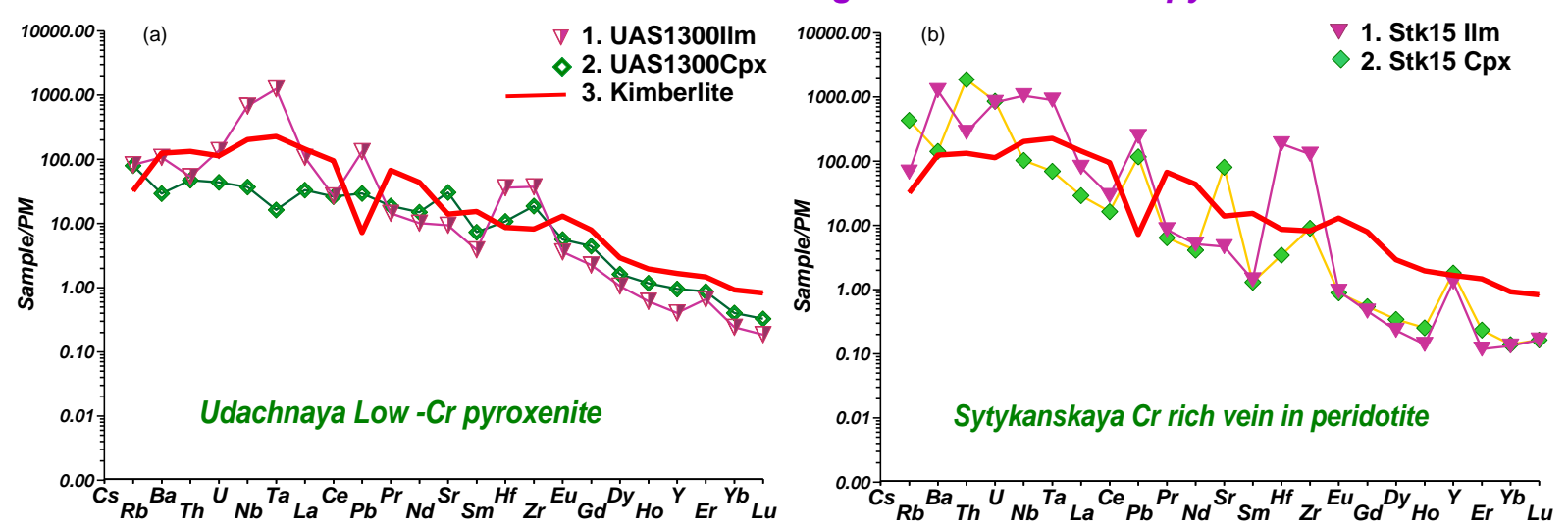

Figure 15. Parental melts for the coexisting ilmenites and clinopyroxenes from low-Cr pyroxenite (UAS1300) (Udachnaya pipe) and metasomatic vein in peridotite xenoliths from the Sytykanskaya pipe (Stk15). Trace element pattern for the Yubileinaya kimberlite (Kostrovitsky et al., 2007) is given for the comparison.

in Mir and in Anabar fields, they form the main part of the ilmenite trends. The fraction of dissolved and crystallized phases regulated the $\mathrm{Cr}$ content of the parental melt. Dissolution of chromite may result in the rapid increase in $\mathrm{Cr}$ of the parental liquid. It is likely that protokimberlites assimilated low-degree hydrous partial melts of metasomatic associations. Increase in $\mathrm{Al}$ may be formed by garnet dissolution. Megacrystalline ilmenite aggregates near the contacts (Fig. 2a) with the peridotites contain up to $2 \% \mathrm{Cr}_{2} \mathrm{O}_{3}$.

The $\mathrm{V}_{2} \mathrm{O}_{5}$ content of ilmenites, reflecting variations of oxygen fugacity conditions $\left(\mathrm{V}_{2} \mathrm{O}_{5}\right)$ of parental magma (Righter et al., 2006; Canil and Fedortchouk, 2000) and wallrock reactions, generally correlates negatively with $\mathrm{MgO}$. Contamination during growth of veins and at their contacts causes variations in the minor components $\mathrm{Cr}_{2} \mathrm{O}_{3}, \mathrm{NiO}$ and $\mathrm{MnO}$. Admixture of $\mathrm{MnO}$ sometimes is rather significant (Patchen et al., 1997). It is common in ilmenites associated with diamonds (Kaminsky et al., 2009) and in some eclogites (De Stefano et al., 2009) it may indicate presence of subducted material in the mantle.

Calculated parental melts for ilmenites using KD for trace elements for ilmenites (Zack and Brumm, 1998; Klemme et al., 2006) show very variable TRE patterns. The compositions of the kimberlite melt for the Yubileynaya pipe (Kostrovitsky et al., 2007) as well as carbonatites from West Greenland (Tappe et al., 2009) and Oldoinyo Lengai (Bell and Simonetti, 1996) are also shown on the diagram.

It is evident that group 1 ilmenites are lower in trace elements except for HFSE than their host kimberlites. The parental melts for group 2 ilmenites were more evolved and produce the patterns close to carbonatites, associated with ailikites (Tappe et al., 2007) and kimberlites. Mostly TRE patterns of group 2 ilmenites have TaNb and ZHf contents close to kimberlitic values or slightly higher. These common ilmenite megacrysts are similar in isotopic features to their host kimberlites (Noyes, 2000; Nowell et al., 2004). HFSE and other incompatible elements.

The melts that crystallized group 3 ilmenites were more enriched than carbonatite from Oldoinyo Lengai (Bell and Simonetti, 1996). This suggests a high degree of fractionation of parental (protokimberlite) melts responsible for megacryst formation (Griffin et al., 1997; Moore et al., 1992) or splitting of the protokimberlites into carbonatite and silicate melts (Safonov et al., 2007). It is possible that they originated from the melt that dissolved some very enriched TRE metasomatites, which includes ilmenites, rutiles and possibly perovskites. Some group 3 ilmenites definitely have admixtures of perovskites which often substitute for ilmenites in grain boundaries (Amishinsky and Pokhilenko, 1984). Some of them, like those from the Anabar fields, reveal significant ZrHf minima.

We calculated the parental melts for the coexisting Cpx and Ilm from a low-Cr pyroxenite xenolith (UAS1300) from the Udachnaya pipe and an Ilm-Cpx vein in a garnet peridotite xenolith (Stk135) (Fig. 15). The parental melts from the first sample are close to equilibrium in REE but the melt calculated from ilmenite is enriched in U-Ta-Nb. The Cpx's parental melt shows a straight line trace element pattern close to that of the kimberlitic with small peaks in $\mathrm{Zr}$ and $\mathrm{Sr}$. The patterns determined for the melts in equilibrium with the metasomatic vein Stk135 show more equilibration but the magma in equilibrium with ilmenite was richer in all HFSE and $\mathrm{Ba}$. This shows that ilmenites crystallized later than $\mathrm{Cpx}$ from the melt that was more enriched in HFSE ( $\mathrm{Zr}, \mathrm{Hf}, \mathrm{Nb}$ and Ta).

The high inclination of the REE patterns may be produced both by melting and fractionation processes which were modeled using combined partition coefficients for Ol, Ilm, $\mathrm{Cpx}$, Opx and Gar. We used the partition coefficients from Bedard (2006) for silicates, and KDs for ilmenites (Zack and 
Brumm, 1998; Klemme et al., 2006). The patterns in Supplement 4 , Fig. $7 \mathrm{a}$, referring to melting to the rather enriched peridotite Ilm-Ol-Gar websterite, show rather low realistic TRE patterns typical for the metasomatic associations. Melting of the depleted association shows highly variable patterns more highly dependent on the melting degree. The fractionation models where $\mathrm{Ol}$ and $\mathrm{Ilm}$ are the main precipitating phases give rather simple conformable patterns (Supplement 4, Fig. 7b). The higher HFSE peaks correspond to significant $\mathrm{Ol}$ fractionation (Supplement 4, Fig. 7c, d).

We also checked the hypothesis of the cognate crystallization trends in $\mathrm{Ta}_{n}-\mathrm{La}_{n}$ diagrams. Calculations of fractionation using olivine (Ol) (90\%) and ilmenite (Ilm) (10\%) as the main crystallizing phases show enrichment by 2 orders of magnitude during nearly complete crystallization of the protokimberlite or carbonatitic melts. Each fractionation trend is restricted by the line with enrichment of $1.3 \log$ units (Supplement 4, Fig. 8). Hence the ilmenites with extreme enrichment to 1000/PM and more should have another mechanism of HFSE enrichment. It could be remelting of ilmeniterutile-bearing associations very enriched in minerals with high TRE contents (apatites, perovskites). Perovskites (found in rims and intergranular spaces) may be responsible for the very high concentration not only HFSE and REE but also Th, $\mathrm{U}$ and LILE. Another mechanism is the immiscible carbonatite melt concentrating TRE.

The trends of the major components (Figs. 3-5) reveal separate lines of enrichment in the $\mathrm{TiO}_{2}$ vs. $\mathrm{Cr}_{2} \mathrm{O}_{3}$ diagram. Probably they reflect repeated pulses of melt within the magmatic feeders. This would have been accompanied by partial remelting of previously formed associations (Ashchepkov and Andre, 2002). This model, with melting of earlier cumulates and metasomatic rocks, explains the rapid enrichment in $\mathrm{TiO}_{2}$ because a simple fractionation model and an origin from the kimberlites could never explain these phenomena. The most realistic mechanism for high enrichment of the incompatible elements including REE and especially HFSE is low-degree partial melting of the contacts with metasomatized associations or the metasomatic front. Mixing of such partial melts with the new portion of protokimberlite melt will cause a strong increase in the trace elements content of the parental megacrystalline liquids.

\subsection{Development of protokimberlites}

Published isotopic data for ilmenites (Noyes, 2000; Kramers et al., 1983; Wagner et al., 1996; Nowell et al., 2004; Schulze et al., 2001; Golubkova et al., 2013) and kimberlites (Tappe et al., 2007, Kostrovitsky et al., 2007) suggest in general their cognate relationships. The most uncontaminated kimberlites and their megacrysts are close to the HIMU asthenospheric component (Agashev et al., 2013; Paton et al., 2009). Their origin is regarded as melting of the carbonated eclogites (Girnis et al., 2011). But abundant precipitating olivine suggests that the primary magma was $\mathrm{Ol}$ normative (Arndt et al., 2010). Presence of two types of ilmenites in kimberlites suggests significant part of olivine I to be xenoliths which were partly dissolved in original magma (Kamenetsky et al., 2008). The group 1 which are low in TRE and are similar in major and TRE components to the group 1 olivine (Kamenetsky et al., 2008). The contacts of such ilmenites with dunites (Fig. 2c) suggest their crystallization in olivine conduits similar to ophiolitic dunite veins containing podiform chromites (González-Jiménez et al., 2014).

Contaminated Cr-bearing megacryst varieties deviate in isotopic diagrams. Most ilmenites parental melts (protokimberlites) are higher in TRE than kimberlites. They were the most evolved and enriched in volatiles portions of melts which derived from the original magma. This agrees with the formation of the megacryst from protokimberlite melts which formed the pre-eruption melt feeder systems and evolved separately from the major magma portions. To receive the positive buoyancy protokimberlite melts should be highly volatile rich and essentially carbonatitic (Russell et al., 2012).

For the development of magmatic system in the mantle before the kimberlite eruption, we suggest a three-stage model (Mitchell, 1986; Le Roex et al., 2003). In the initial stage, ultramafic plume-derived melts containing a significant amount of eclogitic material (Sobolev et al., 2009) intruded the carbonated and hydrated base of the SCLM (Tappe et al., 2007, 2009, 2011). This produced HT depletion of the peridotite and formation of chromites and ilmenites as precipitates in the feeder channels and surrounding wall rocks (rarely sub-calcic garnets may also have grown within and adjacent to the feeders). Partial melting of the metasomatic pyroxenitic aureole enriched in incompatible elements resulted in a high concentration of carbonates, $\mathrm{H}_{2} \mathrm{O}$, silica and HFSE in the secondary hybrid melts which were formed during the next pulse of plume-derived melt.

Contamination and fractionation of secondary alkaline ultramafic magma caused separation into immiscible liquids: silicate, carbonatite, sulfide (Irvine, 1976) and probably oxide (Clarke and Mackay, 1990; Hurai et al., 1998) during cooling. Ilmenites may also have been formed by immiscible oxide melts in the final stages of crystallization (Hurai et al., 1998). Evidence for such melts is seen in xenoliths from the Sytykanskaya pipe where monomineral ilmenite aggregates cut large grains of garnets and other minerals in peridotites.

Rising protokimberlite melts formed due to melting of the enriched metasomatized mantle are similar to kimberlites in REE but have higher incompatible elements including HFSE. Their intrusion during formation of the feeder system produced Ti-rich metasomatism in wall rocks near contacts and heating near the feeder channels. In the channels AFC created the megacrystalline ilmenites which show similar trace element patterns. The assimilated material was the partial melts from the wall rocks which contain melted chromites, thus increasing the $\mathrm{Cr}$ content. According to thermobarometry the fractionation trends commonly stop at the $\sim 4.0 \mathrm{GPa}$ 
boundary, forming the veins and veinlets that represent the metasomatic front. Further pulses of melt intrusion caused remelting of metasomatites and high enrichment in $\mathrm{TiO}_{2}$. Step by step melt intrusion with contamination and partial dissolution of wall-rock resulted in continuous enrichment in $\mathrm{Cr}$ and $\mathrm{TiO}_{2}$ and formation of ilmenite megacrysts which show a stepped $\mathrm{Cr}$ increase such as that found for ilmenites from Zarnitsa, Yubileynaya and other pipes. Three different $\mathrm{Cr}$ trends are found for ilmenites from the Mir pipe.

Possibly contamination and enrichment in water resulted in the formation of the phlogopite-ilmenite veinlets in the peridotites.

The enrichment in TRE may be also the result of incorporation of low-degree melts $(\sim 0.01)$ of hydrous metasomatic rocks in walls of feeders. Fluctuations of Hf, Ba, HFSE, $\mathrm{Y}, \mathrm{Pb}$ and $\mathrm{Sr}$ show that ilmenite crystallization, at least in the last low-temperature stages, was accompanied by growth/dissolution of zircon, rutile, phlogopite, perovskite and apatite (Kalfoun et al., 2002).

During formation of individual pipes, the process of protokimberlite differentiation in the magmatic conduits and chambers may have been a combination of these three simple models.

Variations in $\mathrm{Fe}$ at the same level of $\mathrm{TiO}_{2}$ (Schulze et al., 1995; Nikolenko and Afanasiev, 2008; Robles-Cruz et al., 2009) possibly reflect a multi-stage origin of the ilmenite crystallization trends and reaction with the walls of magmatic conduits.

\subsection{Significance of the ilmenite-bearing association for diamond formation}

The PT conditions for the ilmenites and diamond inclusions especially chromites are often very close and trace heated geotherms and convective branches (Logvinova and Ashchepkov, 2008; Ashchepkov et al., 2010). Even diamondbearing eclogites very often reveal irregular heated conditions associated with metasomatism. In addition the carbonate crystals which always occur in the diamonds in fluids (Logvinova et al., 2008) probably were derived from the protokimberlites which, according to TRE reconstructions, reveal the carbonatite signatures at least at the graphitediamond boundary (Dobosi and Kurat, 2002; Rege et al., 2008). So the most realistic scheme of diamond growth is crystallization near the developing magmatic system during formation of the channels. In these conditions, the reaction of relatively oxidized $\mathrm{CO}_{2}$-rich fluid and melt with reduced peridotite and eclogite was accompanied by crystallization of newly formed diamonds that coated older microdiamonds. The temperatures and $f \mathrm{O}_{2}$ of the ilmenites are slightly higher and their associations and inclusions in diamonds are rare because they reflect different conditions. Ilmenite megacrysts were formed in oxidizing conditions at the internal contacts of feeders and in outer contacts in solidliquid mush forming polymict breccias (Morfi et al., 1999;
Pokhilenko, 2009; Giuliani et al., 2013) and in surrounding metasomatites. Diamonds should mainly crystallize at a distance from feeders in more reduced conditions from the fluid surrounding protokimberlite veins.

\section{Conclusions}

1. Crystallization trends of ilmenites in Siberian kimberlites reflect polybaric fractionation during formation of protokimberlite feeder systems.

2. The correlation of picroilmenite compositions with the mantle layering visible in the Fe\# fluctuations in PT diagrams is explained by interaction of the ilmeniteforming magmas with mantle wall rocks.

3. The regular structure of the mantle sections (i.e., a heated SCLM base and a division into two parts with a boundary near 4.0 GPa (Sobolev, 1974; Ashchepkov et al., 2008a) gives three levels and three possible stages of megacryst origin: (1) deep HT metasomatic pyroxenites and crystallization in the feeding systems; (2) fractionation of protokimberlite melts mixed with partial melt from the peridotite wall rocks; (3) low-degree partial melting of hydrous metasomatic fronts and mixing with evolved protokimberlites.

4. Intrusion of protokimberlite melts rapidly changed the mantle beneath the kimberlite pipes due to large-scale percolation of melts and fluids.

\section{The Supplement related to this article is available online at doi:10.5194/se-5-915-2014-supplement.}

Acknowledgements. The work is supported by RBRF grants: 05-05-64718, 03-05-64146; 08-05-00524; 11-05-00060; 11-0591060-PICS. The work contains the result of the projects 77-2, 65-03, 02-05 UIGGM SD RAS and ALROSA Stock Company. We are grateful to N. V. Sobolev for the consultation about diamond bearing associations, to N. P. Pokhilenko for materials from Udachnaya and other kimberlite pipes, to S. I. Kostrovitsky for the analyses and kimberlite concentrates to A. Moore for discussion about fractionation and models of origin. To T. Ntaflos for the possibility analyze in Vienna University thin sections materials from Udachnaya and Dalnyaya pipes. We are also grateful to $\mathrm{N}$. Arndt for the critical reviews which help to enhance manuscript.

Edited by: D. R. Gröcke 


\section{References}

Afanas'ev, V. P., Nikolenko, E. I., Tychkov, N. S., Titov, A. T., Tolstov, A. V., Kornilova, V. P., and Sobolev, N. V.: Mechanical abrasion of kimberlite indicator minerals: experimental investigations, Russ. Geol. Geophys., 49/2, 91-98, 2008..

Afanasiev, V. P., Ashchepkov, I. V., Verzhak, V. V., O’Brien, H., and Palessky, S. V.: PT conditions and trace element variations of picroilmenites and pyropes from placers and kimberlites in the Arkhangelsk region, NW Russia, J. Asian Earth Sci., 70-71, 45-63, 2013.

Agashev, A. M., Ionov, D. A., Pokhilenko, N. P., Golovin, A. V., Cherepanova, Yu., and Sharygin, I. S.: Metasomatism in lithospheric mantle roots: Constraints from whole-rock and mineral chemical composition of deformed peridotite xenoliths from kimberlite pipe Udachnaya, Lithos, 160-161, 201-215, 2013.

Alymova, N. A.: Peculiarities of ilmenites and ilmenite-bearing association form kimberlites of Yakutian province, Ph.D. dissertation thesis, Irkutsk, Institute of Geochmistry SB RAS, 175, 2006.

Alymova, N. A., Kostrovitsky, S. I., Ivanov, A. S., and Serov, V. P.: Picroilmenites from kimberlites of Daldyn field, Yakutia, Doklady Earth Sci., 395a, 444-447, 2004.

Alymova, N. V., Kostrovitsky, S. I., Yakovlev, D. A., Matsyuk, S. S., Suvorova, L. F., and Solov'eva, L. V.: Ilmenite-bearing mantle parageneses from kimberlite pipes, 9th International Kimberlite Conference Long Abstract, 9IKC-A-00015, 2008.

Amshinsky, A. N. and Pokhilenko, N. P.: Peculiarities of the picroilmenite compositions from Zarnitsa kimberlite pipe (Yakutia), Russ. Geol. Geophys., 24/11, 116-119, 1983.

Arndt, N. T., Guitreau, M., Boullier, A. M., Le Roex, A. P., Tommasi, A., Cordier, P., and Sobolev, A.: Olivine, and the origin of kimberlite, J. Petrol., 51, 573-602, 2010.

Ashchepkov, I. V., Vladykin, N. V., Nikolaeva, I. V., Palessky, S. V., Logvinova, A. M., Saprykin, A. I., Khmel'nikova, O. S., and Anoshin, G. N.: Mineralogy and Geochemistry of Mantle Inclusions and Mantle Column Structure of the Yubileinaya Kimberlite Pipe, Alakit Field, Yakutia, Doklady Earth Sci., 395, 517523, 2004.

Ashchepkov, I. V., Pokhilenko, N. P., Vladykin, N. V., Logvinova, A. M., Kostrovitsky, S. I., Afanasiev, V. P., Pokhilenko, L. N., Kuligin, S. S., Malygina, L. V., Alymova, N. V., Khmelnikova, O. S., Palessky, S. V., Nikolaeva, I. V., Karpenko, M. A., and Stegnitsky, Y. B.: Structure and evolution of the lithospheric mantle beneath Siberian craton, thermobarometric study, Tectonophysics, 485, 17-41, 2010.

Ashchepkov, I. V., André, L., Downes, H., and Belyatsky, B. A.: Pyroxenites and megacrysts from Vitim picrite-basalts (Russia): Polybaric fractionation of rising melts in the mantle?, J. Asian Earth Sci., 42, 14-37, 2011.

Ashchepkov, I. V., Rotman, A. Y., Somov, S. V., Afanasiev, V. P., Downes, H., Logvinova, A. M., Nossyko, S. Shimupi, J., Palessky, S. V., Khmelnikova, O. S., and Vladykin, N. V.: Composition and thermal structure of the lithospheric mantle beneath kimberlite pipes from the Catoca cluster, Angola, Tectonophysics, 530-531, 128-151, 2012.

Ashchepkov, I. V., Vladykin, N. V., Ntaflos, T., Downes, H., Mitchel, R., Smelov, A. P. Rotman, A. Ya., Stegnitsky, Yu., Smarov, G. P, Makovchuk, I. V., Nigmatulina, E. N., and Khmelnikova, O. S.: Regularities of the mantle lithosphere structure and formation beneath Siberian craton in comparison with other cratons, Gondwana Res., 23, 4-24, 2013a.

Ashchepkov, I. V., Ntaflos, T., Kuligin, S. S., Malygina, L. V., Mityukhin, S. I., Vladykin, N. V., Palessky, S. V., Khmelnikova, O. S.: Deep seated xenoliths in Udachnaya pipe from the brown breccia, edited by: Pearson, D. G., Grütter, H. S., Harris, J. W., Kjarsgaard, B. A., O'Brien, H., Chalapathi Rao, N. V., and Sparks, S., Proceedings of 10th International Kimberlite Conference, Volume One, Special Issue of the Journal of the Geological Society of India, doi:10.1007/978-81-322-1170-9_5, 2013b.

Ashchepkov, I. V., Downes, H., Mitchell, R., Vladykin, N. V., Coopersmith, H. and Palessky, S. V.: Wyoming Craton Mantle Lithosphere: Reconstructions Based on Xenocrysts from Sloan and Kelsey Lake Kimberlites, edited by: Pearson, D. G., Grütter, H. S., Harris, J. W., Kjarsgaard, B. A., O'Brien, H., Chalapathi Rao, N. V., and Sparks, S., Proceedings of 10th International Kimberlite Conference, Volume One, Special Issue of the Journal of the Geological Society of India, doi:10.1007/978-81-322-11709, 2013c.

Ashchepkov, I. V., Vladykin, N. N., Ntaflos, T., Kostrovitsky, S. I., Prokopiev, S. A.. Downes, H., Smelov, A. P., Agashev, A. M., Logvinova, A. M., Kuligin, S. S., Tychkov, N. S., Salikhov, R. F., Stegnitsky, Yu. B., Alymova, N. V., Vavilov, M. A., Minin, V. A., Babushkina, S. A., Ovchinnikov, Yu. I., Karpenko, M. A., Tolstov, A. V., and Shmarov, G. P.: Layering of the lithospheric mantle beneath the Siberian Craton: Modeling using thermobarometry of mantle xenolith and xenocrysts, Tectonophysics, doi:10.1016/j.tecto.2014.07.017, 2014.

Aulbach, S., Pearson, N. J., O’Reilly, S. Y., and Doyle, B. J.: Origins of Xenolithic Eclogites and Pyroxenites from the Central Slave Craton, Canada, J. Petrol., 48, 1843-1873, 2007.

Babushkina, S. A. and Marshintsev, V. K.: Composition of spinel, ilmenite, garnet and diopside inclusions in phlogopite macrocrysts from the Mir kimberlite, Russ. Geol. Geophys., 38/2, 440-450, 1997.

Bataleva, Y. V., Palyanov, Y. N., Sokol, A. G., Borzdov, Y. M., and Palyanova, G. A.: Conditions for the origin of oxidized carbonate-silicate melts: Implications for mantle metasomatism and diamond formation, Lithos, 128-131, 113-125, 2012.

Beard, B. L., Fraracci, K. N., Taylor, L. A., Snyder, G. A., Clayton, R. N., Mayeda, T. K., and Sobolev, N. V.: Petrography and geochemistry of eclogites from the Mir kimberlite, Yakutia, Russia, Contrib. Mineral. Petrol., 125, 293-310, 1996.

Bedard, J. H.: A catalytic delamination-driven model for coupled genesis of Archaean crust and sub-continental lithospheric mantle, Geochim. Cosmochim. Ac., 70, 1188-1214, 2006.

Bell, K. and Simonetti, A.: Carbonatite magmatism and plume activity: implications from the $\mathrm{Nd}, \mathrm{Pb}$ and $\mathrm{Sr}$ isotope systematics of Oldoinyo Lengai, J. Petrol., 37, 1321-1339, 1996.

Bizimis, M., Salters, V. J. M., and Dawson B. J.: The brevity of carbonatite sources in the mantle: evidence from Hf isotopes, Contrib. Mineral. Petrol., 145, 281-300, 2003.

Boyd, F. R.: A pyroxene geotherm, Geochim. Cosmochim. Ac., 37, 2533-2546, 1973

Boyd, F. R. and Nixon, P. H.: Origin of the ilmenite-silicate nodules in kimberlites from Lesotho and South Africa, in: edited by: Nixon, P. H., Lesotho Kimberlites, Lesotho National Development Corporation, Maseru, Lesotho, 254-268, 1973. 
Boyd, F. R., Pokhilenko, N. P., Pearson, D. G., Mertzman, S. A., Sobolev, N. V., and Finger, L. W.: Composition of the Siberian cratonic mantle: evidence from Udachnaya peridotite xenoliths, Contrib. Mineral. Petrol., 128, 228-246, 1997.

Brey, G. P. and Kohler, T.: Geothermobarometry in four-phase lherzolites. II. New thermobarometers, and practical assessment of existing thermobarometers, J. Petrol., 31, 1353-1378, 1990.

Canil, D. and Fedortchouk, Y.: Clinopyroxene-liquid partitioning for vanadium and the oxygen fugacity during formation of cratonic and oceanic mantle lithosphere, J. Geophys. Res., 105, 26003-26016, 2000.

Clarke, D. B. and Mackay, R. M.: An Ilmenite-GarnetClinopyroxene nodule from Matsoku: Evidence of Oxide-Rich liquid Immiscibility in Kimberlites?, Canad. Mineral., 28, 229239, 1990.

Dawson, J. B.: Metasomatized harzburgites in kimberlite and alkaline magmas: enriched restites and "flushed" lherzolites. In Mantle Metasomatism, edited by: Menzies, M. A. and Hawkesworth, C. J., Academic Press, London, 125-144, 1987.

Dawson, J. B. and Reid, A. M.: Apyroxene-ilmenite intergrowth from the Monastery Mine, South Africa, Contrib. Mineral. Petrol., 26, 296-301, 1970.

Dawson, J. B. and Smith J.: The MARID (mica-amphibole-rutileilmenite-diopside) suite of xenoliths in kimberlite, Geochim. Cosmochim. Ac., 41, 309-323, 1977.

Dawson, J. B., Hill, P. G., and Kinny, P. D.: Mineral chemistry of a zircon-bearing, composite, veined and metasomatised uppermantle peridotite xenolith from kimberlite, Contrib. Mineral. Petrol., 140, 720-733, 2001.

De Hoog, J. C. M, Gall, G., and Cornell, D. H.: Trace-element geochemistry of mantle olivine and application to mantle petrogenesis and geothermobarometry, Chem. Geol., 270, 196-215, 2010.

De Stefano, A., Kopylova, M. G., Cartigny, P., and Afanasiev, V.: Diamonds and eclogites of the Jericho kimberlite (Northern Canada), Contrib. Mineral. Petrol., 158, 295-315, 2009.

Doucet, L. S., Ionov, D. A., and Golovin, A. V.: The origin of coarse garnet peridotites in cratonic lithosphere: new data on xenoliths from the Udachnaya kimberlite, central Siberia, Contrib. Mineral. Petrol., 165, 1225-1242, 2013.

Eggler, D. H. and Mccallum, M. E.: A geotherm from megacrysts in the Sloan kimberlite pipes, Colorado, Carnegie Institute Washington, Yearbook, 75, 538-541, 1976.

Girnis, A. V., Bulatov, V. K., and Brey, G. P.: Formation of primary kimberlite melts - Constraints from experiments at 6-12 GPa and variable $\mathrm{CO}_{2} / \mathrm{H}_{2} \mathrm{O}$, Lithos, 127, 401-413, 2011.

Giuliani, A., Kamenetsky, V. S., Kendrick, M. A., Phillips, D., Wyatt, B. A. and Maas, R.: Oxide, sulphide and carbonate minerals in a mantle polymict breccia: Metasomatism by proto-kimberlite magmas, and relationship to the kimberlite megacrystic suite, Chem. Geol., 353, 4-18, 2013.

Golubkova, A. B., Nosova, A. A., and Larionova, Yu. O.: Mgilmenite megacrysts from the Arkhangelsk kimberlites, Russia: Genesis and interaction with kimberlite melt and postkimberlite fluid, Geochem. Int., 51, 353-381, 2013.

González-Jiménez, J. M., Griffin, W. L., Proenza, J. A., Gervilla, F., O'Reilly, S. Y., Akbulut, M., Pearson, N. J., and Arai, S.: Chromitites in ophiolites: How, where, when, why? Part II. The crystallization of chromitites, Lithos, 189, 140-158, 2014.
Green, D. H. and, Sobolev, N. V.: Coexisting Garnets and Ilmenites Synthesized at High Pressures from Pyrolite and Olivine Basanite and Their Significance for Kimberlitic Assemblages, Contrib. Mineral. Petrol., 50, 217-229, 1975.

Grégoire, M., Bell, D. R., and Le Roux, A. P.: Trace element geochemistry of glimmerite and MARID mantle xenoliths: their classification and relationship to phlogopite-bearing peridotites and to kimberlites revisited, Contrib. Mineral. Petrol., 142, 603625, 2002.

Grégoire, M., Bell, D. R. and Le Roex, A. P.: Garnet lherzolites from the Kaapvaal craton (South Africa): Trace element evidence for a metasomatic history, J. Petrol., 44, 629-657, 2003.

Griffin, W. L., Cousens, D. R., Ryan, C. G., Sie, S. H., and Suter, G. F.: Ni in chrome pyrope garnets: a new geothermometers, Contrib. Mineral. Petrol., 103, 199-202, 1989.

Griffin, W. L., Moore, R. O., Ryan, C. G., Gurney, J. J., and Win, T. T.: Geochemistry of magnesian ilmenite megacrysts from southern African kimberlites, Russ. Geol. Geophys., 38, 421-443, 1997.

Griffin, W. L., O 'Reilly, S. Y., Abe, N., Aulbach, S., Davies, R. M., Pearson, N. J., Doyle, B.J. and Kivi, K.: The origin and evolution of Archean lithospheric mantle, Precambrian Res., 127, 19-41, 2003.

Griffin, W. L., O'Reilly, S. Y., Doyle, B. J., Pearson, N. J., Coopersmith, H., Kivi, K., Malkovets, V., and Pokhilenko, N.: Lithosphere mapping beneath the North American plate, Lithos, 77, 873-922, 2004.

Gudmundsson, G. and Wood, B. J.: Experimental tests of garnet peridotite oxygen barometry, Contrib. Mineral. Petrol., 119, 5667, 1995.

Gurney, J. J., Fesq, H. W., and Kable, E. J. D.: Clinopyroxeneilmenite intergrowths from kimberlite: are-appraisal, in: Lesotho Kimberlites, Nixon, P. H., Lesotho National Development Corporation, Maseru, Lesotho, 238-253, 1973.

Gurney, J. J., Jakob, W. R. O. and Dawson, J. B.: Megacrysts from the Monastery kimberlite pipe, South Africa, in: Proceedings of the Second International Kimberlite Conference, edited by: Boyd, F. R. and Meyer, H. O. A., American Geophysical Union, The Mantle Sample: Inclusions in Kimberlites and Other Volcanics, 2, 227-243, 1979.

Gurney, J. J., Moore, R. O., and Bell, D. R.: Mineral associations and compositional evolution of Monastery kirnberlite megacrysts, in: 7th International Kimberlite Conference, Extended Abstracts, 290-292, 1998.

Haggerty, S. E.: The mineral chemistry of new titanates from the Jagersfontein kimberlite, South Africa: Implications for metasomatism in the upper mantle, Geochim. Cosmochim. Ac., 47, 1833-1854, 1983.

Haggerty, S. E.: Upper mantle opaque stratigraphy and the genesis of metasomites and alkali-rich melts. Kimberlites and Related Rocks, Proc. 4th Int. Kimberlite Conf., Vol.2. Special Publication, GSA, 14, 687-699, 1989.

Haggerty, S. E.: Upper mantle mineralogy, J. Geodynam., 20, 331364, 1995.

Haggerty, S. E. and Tompkins, L. A.: Redox state of the earth's upper mantle from kimberlitic ilmenites, Nature, 303, 295-300, 1983.

Haggerty, S. E. and Tompkins, L. A.: Subsolidus reactions in kimberlitic ilmenite: exsolution, reduction and the redox state of the 
mantle, in: Kimberlites I: Kimberlites and Related Rocks, edited by: Kornprobst, J., Proc. 3rd Int. Kimb. Conf., Elsevier, Amsterdam, 335-357, 1984.

Haggerty, S. E., Hardie, R. B., and McMahon, B. M.: The mineral chemistry of ilmenite nodule associations from the Monastery diatreme, in: The Mantle Sample: Inclusions in kimberlites and other volcanic, edited by: Boyd, F. R., and Meyer, H. O. A., American Geophysical Union, Washington, DC, 249-256, 1979.

Hamilton, M. A., Pearson, D. G., Stern, R. A., and Boyd, F. R.: Constraints on MARID petrogenesis: SHRIMP II U-Pb zircon evidence for pre-eruptive metasomatism at Kampfersdam. Extended Abstracts of the 7th International Kimberlite Conference, Cape Town, University of Cape Town Press, 296-298, 1998.

Harte, B.: Metasomatic events recorded in mantle xenoliths: an overview, in: Mantle Xenoliths, edited by: Nixon, P. H., Wiley, Chichester, 625-640, 1987.

Harte, B. and Gurney, J. J.: Ore mineral and phlogopite mineralization within ultramafic nodules from the Matsoku kimberlite pipe, Lesotho. Carnegie Institute Washington, Yearbook 74, 528-536, 1975.

Heaman, L., Creaser, R. A., Cookenboo, H., and Chacko, T.: Multistage modification of the Northern Slave mantle lithosphere: evidence from zircon- and diamond-bearing eclogite xenoliths entrained in Jericho kimberlite, Canada, J. Petrol., 47, 821-858, 2006.

Hills, D. V. and Haggerty, S. E. Petrochemistry of eclogites from the Koidu Kimberlite Complex, Sierra Leone, Contrib. Mineral. Petrol., 103, 397-422, 1989.

Hunter, R. H. and Taylor, L. A. Magma-mixing in the low velocity zone: kimberlitic megacrysts, Am. Mineral., 69, 16-29, 1984.

Hurai, V., Simon, K., Wiechert, U., Hoefs J., Konec P., Huraiova, M., Pironon, J., and Lipka, J.: Immiscible separation of metalliferous Fe/Ti-oxide melts from fractionating alkali basalt: $\mathrm{P}-\mathrm{T}-\mathrm{fO}_{2}$ conditions and two-liquid elemental partitioning, Contrib. Mineral. Petrol., 133, 12-29, 1998.

Ionov, D. A., Doucet, L. S., and Ashchepkov, I. V.: Composition of the Lithospheric Mantle in the Siberian Craton: New Constraints from Fresh Peridotites in the Udachnaya-East Kimberlite, J. Petrol., 51, 2177-2210, 2010.

Irvine, T. N.: Metastable liquid immiscibility and $\mathrm{MgO}-\mathrm{FeO}-$ $\mathrm{SiO}_{2}$ fractionation patterns in the system $\mathrm{Mg}_{2} \mathrm{SiO}_{6}-\mathrm{FeSiO}_{3}-$ $\mathrm{CaAl}_{2} \mathrm{Si}_{2} \mathrm{O}_{6}-\mathrm{KAlSi}_{3} \mathrm{O}_{8}-\mathrm{SiO}_{2}$, Carnegie Institute Washington Yearbook, 75, 597-611, 1976.

Kadik, A. A., Sobolev, N. V., Zharkova, E. V., and Pokhilenko, N. P.: Redox-state conditions of the creation of diamond bearing peridotites from Udachnaya kimberlite pipe, Geochem. Int., 8, 1120-1135, 1989.

Kalfoun, F., Ionov, D. and Merlet, C.: HFSE residence and $\mathrm{Nb} / \mathrm{Ta}$ ratios in metasomatised, rutile-bearing mantle peridotites, Earth Planet. Sc. Lett., 199, 49-65, 2002.

Kamenetsky, V. S., Kamenetsky M. B., Sobolev A. V., Golovin A. V., Demouchy S., Faure K., Sharygin V. V., and Kuzmin, D. V.: Olivine in the Udachnaya-East Kimberlite (Yakutia, Russia): types, compositions and origins, J. Petrol., 49, 823-839, 2008.

Kaminsky, F. V. and Belousova, E. A. Manganoan ilmenite as kimberlite/diamond indicator mineral, Russ. Geol. Geophys., 50, 1212-1220, 2009.

Kaminsky, F. V., Zakharchenko O. D., Davies R., Griffin W. L., Khachatryan-Bilnova G. K., and Shiryaev A. A.: Superdeep dia- monds from the Juina area, Mato Grosso State, Brazil, Contrib. Mineral. Petrol., 140, 734-753, 2001.

Karki, B. B. I, Duan, W., Da Silva, C. R. S., and Wentzcovitch, R. M.: Ab initio structure of $\mathrm{MgSiO}_{3}$ ilmenite at high pressure, $\mathrm{Am}$. Mineral., 85, 317-320, 2000.

Kennedy, C. S. and Kennedy, G. C.: The equilibrium boundary between graphite and diamond, J. Geophys. Res., 8, 12467-2470, 1976.

Klemme, S., Gunther, D., Hametner, K., Prowatke, S., and Zack, T.: The partitioning of trace elements between ilmenite, ulvospinel, armalcolite and silicate melts with implications for the early differentiation of the Moon, Chem. Geol., 234, 251-263, 2006.

Konzett, J., Armstrong, R. A., and Gunther, D.: Modal metasomatism in the Kaapvaal craton lithosphere: constraints on timing and genesis from U-Pb zircon dating of metasomatized peridotites and MARID-type xenoliths, Contrib. Mineral. Petrol., 139, 704-719, 2000.

Kopylova, M. G., Nowell, G. M., Pearson, D. G., and Markovic, G.: Crystallization of megacrysts from protokimberlitic fluids: geochemical evidence from high-Cr megacrysts in the Jericho kimberlite, Lithos, 112, 284-295, 2009.

Kostrovitsky, S. I. and Bruin, D. Chromium association of minerals in micaceous kimberlites of the Daldyn field (Yakutian province), Russ. Geol. Geophys., 45, 565-576, 2004.

Kostrovitsky, S. I., Alymova, N. V., Ivanov, A. S., and Serov, V. P.: Structure of the Daldyn Field (Yakutian Province) Based on the Study of Picroilmenite Composition, Extended Abstracts of the 8th International Kimberlite Conference, FLA_0207, 2003.

Kostrovitsky, S. I., Malkovets, V. G., Verichev, E. M., Garanin, V. K., and Suvorova, L. V.: Megacrysts from the Grib kimberlite pipe (Arkhangelsk Province, Russia), Lithos, 77, 511-523, 2004.

Kostrovitsky, S. I., Morikiyo, T., Serov, I. V., Yakovlev, D. A., and Amirzhanov, A. A.: Isotope-geochemical systematics of kimberlites and related rocks from the Siberian Platform, Russ. Geol. Geophys., 48, 272-290, 2007.

Kramers, J. D., Roddick, J. C. M., and Dawson, J. B.: Trace element and isotope studies on veined, metasomatic and "MARID" xenoliths from Bultfontein, South Africa, Earth Planet. Sc. Lett., 65, 90-106, 1983.

Kuligin, S. S.: Complex of pyroxenite xenoliths in kimberlites from different regions of Siberian platform, Ph.D. thesis, United Institute of Geology Geophysics, Mineralogy, Novosibirsk, 250, 1996.

Kurszlaukis, S., Mahotkin, I., Rotman, A. Y., Kolesnikov, G. V., and Makovchuk, I. V.: Syn- and post-eruptive volcanic processes in the Yubileinaya kimberlite pipe, Yakutia, Russia, and implications for the emplacement of South African-style kimberlite pipes, Lithos, 112, 579-591, 2008.

Lapin, A. V., Tolstov, A. V., and Vasilenko, V. B.: Petrogeochemical characteristics of the kimberlites from the Middle Markha region with application to the problem of the geochemical heterogeneity of kimberlites, Geochem. Int., 45, 1197-1209, 2007.

Lavrent'ev, Yu. G. and Usova, L. V.: New version of KARAT program for quantitative X-ray spectral microanalysis, Zhurnal Analiticheskoi Khimii, 5, 462-468, 1994.

Lavrentyev, Y. G., Usova, L. V., Kuznetsova, A. I. and Letov, S. V.: $\mathrm{X}$-ray spectral quant metric microanalysis of the most important minerals of kimberlites, Russ. Geol. Geophys., 48, 75-81, 1987. 
Le Roex, A. P., Bell, D. R., and Davis, P.: Petrogenesis of group I kimberlites from Kimberley, South Africa: Evidence from bulkrock geochemistry, J. Petrol., 44, 2261-2286, 2003.

Liu, L.: High-pressure phase transformations and compressions of ilmenite and rutile: I. Experimental results, Phys. Earth Planet. Int., 10, 167-176, 1975.

Logvinova, A. M. and Ashchepkov, I. V.: Diamond inclusions and eclogites thermobarometry, Siberia, Goldschmidt Conference Abstracts, Geochim. Cosmochim. Ac., Special Supplement, 72, 16S, A567, 2008.

Logvinova, A. M., Taylor, L. A., Floss, C., and Sobolev, N. V.: Geochemistry of multiple diamond inclusions of harzhurgitic garnets as examined in situ, Int. Geol. Rev., 47, 1223-1233, 2005.

Logvinova, A. M., Wirth, R., Fedorova, E. N., and Sobolev, N. V.: Nanometre-sized mineral and fluid inclusions in cloudy Siberian diamonds: new insights on diamond formation, Eur. J. Mineral., 20, 317-331, 2008.

Malygina, E. V.: Xenoliths of granular mantle peridotites in Udachnaya pipe. Ph.D. thesis, United Institute of Geology Geophysics, Mineralogy, Novosibirsk, 270 pp., 2000.

McCallister, R. H., Meyer, H. O. A., and Brookins, D. G.: "Pyroxene"-Ilmenite xenoliths from the Stockdale pipe, Kansas: Chemistry, crystallography, and origin, Phys. Chem. Earth, 9, 287-293, 1975.

McCammon, C. A. and Kopylova, M. G.: A redox profile of the Slave mantle and oxygen fugacity control in the cratonic mantle, Contrib. Mineral. Petrol., 148, 55-68, 2004.

McCammon, C. A., Chinn, I. L., Gurney, J. J., and McCallum, M. E.: Ferric iron content of mineral inclusions in diamond from George Creek, Colorado, determined using Mössbauer spectroscopy, Contrib. Mineral. Petrol., 133, 30-37, 1998.

McDonough, W. F. and Sun, S. S.: The Composition of the Earth, Chem. Geol., 120, 223-253, 1995.

McGregor, I. D.: The system $\mathrm{MgO}-\mathrm{SiO}_{2}-\mathrm{Al}_{2} \mathrm{O}_{3}$ : solubility of $\mathrm{Al}_{2} \mathrm{O}_{3}$ in enstatite for spinel and garnet peridotite compositions, Am. Mineral., 59, 110-119, 1974.

Meyer, H. O. A. and Svisero, D. P.: Mineral inclusions in Brazilian diamonds, Phys. Chem. Earth, 9, 785-795, 1975.

Mitchell, R. H.: Magnesian ilmenite and its role in kimberlite petrogenesis, J. Geol., 81, 301-311, 1973.

Mitchell, R. H.: Geochemistry of magnesian ilmenites from kimberlites in South Africa and Lesotho, Lithos, 10, 29-37, 1977.

Mitchell, R. H.: Kimberlites: Mineralogy, Geochemistry and Petrology, Plenum Press, New York, 442 pp., 1986.

Moore, A. and Belousova, E.: Crystallization of Cr-poor and Cr-rich megacryst suites from the host kimberlite magma: implications for mantle structure and the generation of kimberlite magmas, Contrib. Mineral. Petrol., 49, 462-481, 2005.

Moore, A. E. and Lock, N. P.: The origin of mantle-derived megacrysts and sheared peridotites - evidence from kimberlites in the northern Lesotho - Orange Free State (South Africa) and Botswana pipe clusters, S. Afr. J. Geol., 104, 23-38, 2001.

Moore, A.: Type II diamonds: Flamboyant megacrysts, S. Afr. J. Geol., 112, 23-38, 2009.

Moore, R. O., Griffin, W. L., Gurney, J. J, Ryan, C. G., Cousens, D. R., Sie, S. H., and Suter, G. F., Trace element geochemistry of ilmenite megacrysts from the Monastery kimberlite, South Africa, Lithos, 29, 1-18, 1992.
Morfi, L, Harte, B, Hill, P., and Gurney, J.: Polymict peridotites: a link between deformed peridotites and megacrysts from kimberlites, Ofioliti, 24, p. 134, 1999.

Neal, C. R. and Davidson, J. P.: An unmetasomatized source for the Malaitan Alnoite (Solomon Islands); petrogenesis involving zone refining, megacryst fractionation, and assimilation of oceanic lithosphere, Geochim. Cosmochim. Ac., 53, 1975-1990, 1989.

Nikolenko, E. I. and Afanasiev, V. P.: Peculiarities of the composition of zoned picroilmenites from the Massadou field (Guinea) and Dachnaya pipe (Yakutia) kimberlites, Dokl. Earth Sci., 434, 1386-1389, 2010.

Nimis, P. and Taylor, W.: Single clinopyroxene thermobarometry for garnet peridotites. Part I. Calibration and testing of a Crin-Cpx barometer and an enstatite-in-Cpx thermometer, Contrib. Mineral. Petrol., 139, 541-554, 2000.

Nixon, P. H. (Ed.): Kimberlitic xenoliths and their cratonic setting. In: Mantle Xenoliths, John Wiley and Sons Ltd., 215-239, 1987.

Nixon, P. H.: A review of mantle xenoliths and their role in diamond exploration, J. Geodynam., 20, 305-329, 1995.

Nixon, P. H. and Boyd, F. R.: Garnet bearing lherzolite and discrete nodule suites from the Malaite alnoite, Solomon Islands, SW Pacific, and their bearing on oceanic mantle composition and geotherm, in: The mantle sample: Inclusions in kimberlites and other volcanics, Am. Geophys. Un., 400-423, 1979.

Nowell, G. M., Pearson, D. G., Bell, D. R., Carlson, R. W., Smith, C. B., Kempton, P. D., and Noble, S. R.: Hf Isotope Systematics of Kimberlites and their Megacrysts: New Constraints on their Source Regions, J. Petrol., 45, 1583-1612, 2004.

Noyes, A. K.: Feasibility Study of U-Pb Ilmenite Geochronology, Monastery Kimberlite, South Africa, Thesis for degree of Master of Science, University of Alberta Edmonton, Alberta Spring, 88 pp., 2000.

O’Reilly, S. Y., Zhang, M., Griffin, W. L., Begg, G., and Hronsky, J.: Ultradeep continental roots and their oceanic remnants: A solution to the geochemical "mantle reservoir" problem?, Lithos, 1122, 1043-1054, 2009.

Ovchinnikov, Yu. I.: Xenoliths from Obnazhennaya kimberlite pipe and alkali basalts from Minusa depression, Ph.D. disertation thesis, United Institute of Geology Geophysics, Mineralogy, Novosibirsk, 225 pp., 1990.

Pasteris, J. D.: The significance of groundmass ilmenite and megacryst ilmenite in kimberlites, Contrib. Mineral. Petrol., 75, 315-325, 1980.

Patchen, A. D., Taylor, L. A., and Pokhilenko, N. P.: Ferrous freudenbergite in ilmenite megacrysts: A unique paragenesis from the Dalnaya kimberlite, Yakutia, Am. Mineral., 82, 9911000, 1997.

Paton, C., Hergt, J. M., Woodhead, J. D. Phillips, D., and Shee S. R.: Identifying the asthenospheric component of kimberlite magmas from the Dharwar Craton, India, Lithos, 112, 296-310, 2010.

Pearson, D. G., Canil, D., and Shirey, S. B.: Mantle samples included in volcanic rocks: xenoliths and diamonds, in: Treatise on Geochemistry, 2: The Mantle and Core, edited by: Turekian, K. K. and Holland, H. D., Amsterdam, Elsevier, 171-275, 2003.

Peslier, A. H., Woodland, A., Bell, D. R., Lazarov, M., and Lapen T. J.: Metasomatic control of water contents in the Kaapvaal cratonic mantle, Geochim. Cosmochim. Ac., 97, 213-246, 2012. 
Pokhilenko, L. N.: Volatile composition and oxidation state of mantle xenoliths from Siberian kimberlites, Ph.D. thesis, United Institute of Geology Geophysics, Mineralogy, Novosibirsk, 225 pp., 2006.

Pokhilenko, N. P.: Polymict breccia xenoliths: Evidence for the complex character of kimberlite formation, Lithos, 109, 934941, 2009.

Pokhilenko, N. P., Sobolev, N. V., Sobolev, V. S., and Lavrentiev, Y. G.: Xenoliths of diamond bearing ilmenite-pyrope lherzolites from the kimberlite pipe Udachnaya (Yakutia), Doklady AN SSSR, 231, 438-442, 1976

Pokhilenko, N. P., Pearson, D. G., Boyd, F. R., and Sobolev, N. V.: Megacrystalline dunites: sources of Siberian diamonds, Carnegie Institute Washington, Yearbook, 90, 11-18, 1991.

Pokhilenko, N. P., Sobolev, N. V., Kuligin, S. S., and Shimizu, N.: Peculiarities of distribution of pyroxenite paragenesis garnets in Yakutian kimberlites and some aspects of the evolution of the Siberian craton lithospheric mantle, Proceedings of the VII International Kimberlite Conference, The P. H. Nixon volume, 690 707, 1999

Ponomarenko, A. I.: First find of a diamond bearing garnet-ilmenite peridotite in the Mir kimberlite pipe, Doklady AN SSSR, 235, I53-I56, 1971.

Pyle, J. M. and Haggerty, S. E.: Eclogites and the metasomatism of eclogites from the Jagersfontein Kimberlite: Punctuated transport and implications for alkali magmatism, Geochim. Cosmochim. Ac., 62, 1207-1231, 1998.

Rege, S., Griffin, W. L., Kurat, G., Jackson, S. E., Pearson, N. J., and O'Reilly S. Y.: Trace-element geochemistry of diamondite: Crystallisation of diamond from kimberlite-carbonatite melts, Lithos, 106, 39-54, 1998.

Reimers, L. F.: Deep seated mineral associations of the kimberlites pipe Sytycanskaya (materials of the study of mantle rock and crystalline inclusions in diamonds), Institute of Geology and Geophysics, Novosibirsk, 258 pp., 1994.

Reimers, L. F., Pokhilenko, N. P., Yefimova, E. S., and Sobolev, N. V.: Ultramafic mantle assemblages from Sytykanskaya kimberlite pipe (Yakutia), Seventh International Kimberlite Conference, Cape Town, April 1998, Extended Abstracts, Cape Town, 730732, 1998.

Reynard, B. G., Fiquet, G., Itie, J.-P., and Rubie, D.C.: Highpressure X-ray diffraction study and equation of state of $\mathrm{MgSiO}_{3}$ ilmenite, Am. Mineral., 81, 45-50, 1996.

Righter, K., Leeman, W. P., and Hervig, R. L.: Partitioning of Ni, Co and $\mathrm{V}$ between spinel-structured oxides and silicate melts: Importance of spinel composition, Chem. Geol., 227, 1-25, 2006.

Ringwood, A. E. and Lovering, J. F.: Significance of pyroxene ilmenite intergrowths among Kimberlite xenoliths, Earth Planet. Sc. Lett., 7, 371-375, 1970.

Robles-Cruz, S. E., Watangua, M., Isidoro, L., Melgarejo, J. C., Galí, S., and Olimpio, A.: Contrasting compositions and textures of ilmenite in the Catoca kimberlite, Angola, and implications in exploration for diamond, Lithos, 112, 966-975, 2009.

Roden, M. F., Patiño-Douce, A. E., Jagoutz, E., and Laz'ko, E. E.: High pressure petrogenesis of Mg-rich garnet pyroxenites from Mir kimberlite, Russia, Lithos, 90, 77-91, 2006.

Rodionov, A. S., Amshinsky, A. N., and Pokhilenko, N. P.: IlmenitePyrope wehrlite - a new type of kimberlite xenoliths paragenesis, Russ. Geol. Geophys., 19, 53-57, 1988.
Rodionov, A. S., Sobolev, N. V., Pokhilenko, N. P., Suddaby, P., and Amshinsky, A. N.: Ilmenite-bearing peridotites and megacrysts from Dalnaya kimberlite pipe, Yakutia, Fifth International Kimberlite Conference, Extended abstracts, USA, 339-341, 1991.

Rowlinson, P. J. and Dawson, B. J.: A quench pyroxene- ilmenite xenolith in kimberlite: implications for the pyroxene- ilmenite intergrowth, in: Proceedings of the Second International Kimberlite Conference, edited by: Boyd, F. R. and Meyer, H. O. A., American Geophysical Union, The Mantle Sample: Inclusions in Kimberlites and Other Volcanics, 2, 292-299, 1979.

Russell, J. K., Porritt, L. A., Lavallée, Y., and Dingwell, D. W.: Kimberlite ascent by assimilation-fuelled buoyancy, Nature, 481, 352-356, 2012.

Safonov, O. G., Perchuk, L. L., and Litvin, Y. A.: Melting relations in the chloride-carbonate-silicate systems at high-pressure and the model for formation of alkalic diamond-forming liquids in the upper mantle, Earth Planet. Sc. Lett., 253, 112-128, 2007.

Schulze, D. J., Valley, J. R., Bell, D. R., and Spicuzza, M. J.: Oxygen isotope variations in $\mathrm{Cr}$-poor megacrysts from kimberlite, Geochim. Cosmochim. Ac., 65, 4375-4384, 2001.

Schulze, D. L., Anderson, P. F. N., Hearn Jr., B. C., and Hetman, C. M.: Origin and significance of ilmenite megacrysts and macrocrysts from kimberlite, Int. Geol. Rev., 37, 780-812, 1995.

Simon, N. S. C., Irvine, G. J., Davies, G. R., Pearson, D. G., and Carlson, R. W.: The origin of garnet and clinopyroxene in "depleted" Kaapvaal peridotites, Lithos, 71, 289-322, 2003.

Smith, J. V. and Dawson, J. B.: Chemistry of Ti-poor spinels, ilmenites and rutiles from peridotite and eclogite xenoliths, Phys. Chem. Earth, 309, 9-32, 1975.

Snyder, G. A., Taylor, L. A., Crozaz, G., Halliday, A. N., Beard, B. L., and Sobolev, V. N.: The Origins of Yakunan Eclogite Xenoliths, J. Petrol., 38, 85-113, 1997.

Sobolev, A. V., Sobolev, S. V., Kuzmin, D. V., Malitch, K. N., and Petrunin, A. G.: Siberian meimechites: origin and relation to flood basalts and kimberlites, Russ. Geol. Geophys., 50, 9991033, 2009.

Sobolev, N. V.: Deep-Seated Inclusions in Kimberlites and the Problem of the Composition of the Mantle, Am. Geophys. Un., Washington, DC, 279 pp., 1974.

Sobolev, N. V.: Significance of picroilmenite for the localization of kimberlite fields, Russ. Geol. Geophys., 24, 149-151, 1980.

Sobolev, N. V. and Yefimova, E. S.: Composition and petrogenesis of Ti-oxides associated with diamonds, Int. Geol. Rev., 42, 758767, 2000.

Sobolev, N. V., Kharkiv, A. D., Lavrent'ev, Y. G., and Pospelova, L. N.: Zonal garnet with inclusion of Cr-spinel and ilmenite from Mir kimberlite pipe, Russ. Geol. Geophys., 6, 124-128, 1975.

Sobolev, N. V., Pokhilenko, N. V., and Efimova, E. S.: Xenoliths of diamond bearing peridotites in kimberlites and problem of the diamond origin, Russ. Geol. Geophys., 25, 63-80, 1984.

Sobolev, N. V., Kaminsky, F. V., Griffin, W. L., Yefimova, E. S., Win, T. T., Ryan, C. G., and Botkunov, A. I.: Mineral inclusions in diamonds from the Sputnik kimberlite pipe, Yakutia, Lithos, 39, 135-157, 1997.

Sobolev, N. V., Logvinova, A. M., Zedgenizov, D. A., Yefimova, E. S., Taylor, L. A., Promprated P., Koptil, V. I., and Zinchuk, N. N.: Mineral Inclusions in Diamonds from Komsomolskaya and Krasnopresnenskaya Pipes, Yakutia: Evidence for Deep Lithospheric Heterogeneities in Siberian Craton, 8th Interna- 
tional Kimberlite conference, Victoria, BC, Extended Abstracts, FLA_0141, 2003.

Sobolev, N. V., Logvinova, A. M., Zedgenizov, D. A., Pokhilenko, N. P., Kuzmin, D. V., and Sobolev, A. V.: Olivine inclusions in Siberian diamonds: high-precision approach to minor elements, Eur. J. Mineral, 20, 305-315, 2008.

Sobolev, N. V., Logvinova, A. M., and Efimova, E. S.: Syngenetic phlogopite inclusions in kimberlite-hosted diamonds: implications for role of volatiles in diamond formation, Russ. Geol. Geophys., 50, 1234-1248, 2009.

Solov'eva, L. V., Lavrent'ev, Yu. G., Egorov, K. N., Kostrovitskii, S. I., Korolyuk, V. N., and Suvorova, L. F.: The genetic relationship of the deformed peridotites and garnet megacrysts from kimberlites with asthenospheric melts, Russ. Geol. Geophys., 49, $207-$ 224, 2008.

Solovieva, L. V., Egorov, K. N., Markova, M. E., Kharkiv, A. D., Popolitov, K. E., and Barankevich, V. G.: Mantle metasomatism and melting in deep-seated xenoliths from the Udachnaya pipe, their possible relationship with diamond and kimberlite formation, Russ. Geol. Geophys., 38, 172-193, 1997.

Spetsius, Z. V.: Petrology of highly aluminous xenoliths from kimberlites of Yakutia, Lithos, 77, 525-538, 2004.

Spetsius, Z. V., Belousova, E. A., Griffin, W. L., O'Reilly, S. Y., and Pearson, N. J.: Archean sulfide inclusions in Paleozoic zircon megacrysts from the Mir kimberlite, Yakutia: implications for the dating of diamonds, Earth Planet. Sc. Lett., 199, 111-126, 2002.

Stachel, T. and Harris, J. W.: The origin of cratonic diamonds Constraints from mineral inclusions, Ore Geol. Rev., 34, 5-32, 2008.

Stachel, T., Harris, J. W., and Brey, G. P.: Rare and unusual mineral inclusions in diamonds from Mwadui, Tanzania, Contrib. Mineral. Petrol., 132, 34-47, 2004.

Stagno, V. and Frost, D. J.: Carbon speciation in the asthenosphere: experimental measurements of the redox conditions at which carbonate - bearing melts coexist with graphite or diamond in peridotite assemblages, Earth Planet. Sc. Lett., 300, 72-84, 2010.

Tappe, S., Foley, S. F., Stracke, A., Romer, R. L., Kjarsgaard, B. A., Heaman, L. M., and Joyce, N.: Craton reactivation on the Labrador Sea margins: ${ }^{40} \mathrm{Ar} /{ }^{39} \mathrm{Ar}$ age and $\mathrm{Sr}-\mathrm{Nd}-\mathrm{Hf}-\mathrm{Pb}$ isotope constraints from alkaline and carbonatite intrusives, Earth Planet. Sc. Lett., 256, 433-445, 2007.

Tappe, S., Steenfelt, A., Heamana, L. M., and Simonetti, A.: The newly discovered Jurassic Tikiusaaq carbonatite-aillikite occurrence, West Greenland, and some remarks on carbonatitekimberlite relationships, Lithos, 112, 385-399, 2009.
Tappe, S., Pearson, D. G., Nowell, G., Nielsen, T., Milstead, P., and Muehlenbachs, K.: A fresh isotopic look at Greenland kimberlites: Cratonic mantle lithosphere imprint on deep source signal, Earth Planet. Sc. Lett., 305, 235-248, 2011.

Taylor, L. A. and Anand, M.: Diamonds: time capsules from the Siberian Mantle, Chemie der Erde, 64, 1-74, 2004.

Taylor, L. A., Gregory, A., Keller, S. R., Remley, D. A., Anand, M., Wiesli, R. Valley, J., and Sobolev, N. V.: Petrogenesis of group A eclogites and websterites: evidence from the Obnazhennaya kimberlite, Yakutia, Contrib. Mineral. Petrol., 145, 424-443, 2003.

Taylor, W. L., Kamperman, M. and Hamilton, R.: New thermometer and oxygen fugacity sensor calibration for ilmenite amd Crspinel- bearing peridotite assemblage, in: 7th International Kimberlite Conference, edited by: Gurney, J. J., Gurney, J. L., Pascoe, M. D., Richardson, S. H., Red Roof Design, Capetown, 896, 1998.

Wagner, C., Deloule, E., and Mokhtari, A.: Richterite-bearing peridotites and MARID-type inclusions in lavas from North Eastern Morocco: mineralogy and D/H isotopic studies, Contrib. Mineral. Petrol., 124, 406-421, 1996.

Wirth, R., Kaminsky, F., Matsyuk, S. and Schreiber, A.: Unusual micro- and nano-inclusions in diamonds from the Juina Area, Brazil, Earth Planet. Sc. Lett., 286, 292-303, 2009.

Wyatt, B. A. and Lawless, P. J.: Ilmenite in polymict xenoliths from the Bultfontein and De Beers Mines, South Africa, in: Kimberlites II: Their Mantle and Crust/Mantle Relationships, edited by: Kornprobst, J., Proc. 3rd Int. Kimb. Conf. Elsevier, Amsterdam, 43-56, 1984.

Wyatt, B. A., Baumgartner, M., Anckar, E., and Grutter, H.: Compositional classification of "kimberlitic" and "non-kimberlitic" ilmenite, Lithos, 77, 819-840, 2004.

Zack, T. and Brumm, R.:. Ilmenite/liquid partition coefficients of 26 trace elements determined through ilmenite/clinopyroxene partitioning in garnet pyroxenite, in: 7th International Kimberlite Conference, edited by: Gurney, J. J., Gurney, J. L., Pascoe, M. D., and Richardson, S. H., Red Roof Design, Capetown, 986988, 1998.

Zhang, H. F., Menzies, M. A., Mattey, D. P., Hinton R. W., and Gurney J. J.: Petrology, mineralogy and geochemistry of oxide minerals in polymict xenoliths from the Bultfontein kimberlites, South Africa: implication for low bulk-rock oxygen isotopic ratios, Contrib. Mineral. Petrol., 141, 367-379, 2001.

Zhao, D., Essene, E. J., and Zhang, Z.: An oxygen barometer for rutile-ilmenite assemblages: oxidation state of metasomatic agents in the mantle, Earth Planet. Sc. Lett., 166, 127-137, 1999. 